\title{
Neuropeptide Receptors in Pain Circuitries: Useful Targets for CNS Imaging with Non-Peptide Ligands Suitable for PET?
}

\author{
Margit Pissarek \\ INM-5 Nuclear Chemistry, Institute of Neurosciences and Medicine, Research Centre Jülich, Jülich, Germany \\ Email: $\underline{\text { m.pissarek@fz-juelich.de }}$
}

Received 15 June 2014; revised 15 July 2014; accepted 26 July 2014

Copyright (C) 2014 by author and Scientific Research Publishing Inc. This work is licensed under the Creative Commons Attribution International License (CC BY). http://creativecommons.org/licenses/by/4.0/

(c) (i) Open Access

\begin{abstract}
Neuropeptide receptors of the brain and spinal cord are parts of the pain circuits targeted by analgesic drugs. Some of these receptors have been found in the central nervous system as well as in intracranial vascular structures and achieved revival of attention because of their role in acute and chronic pain syndromes. A number of them are of high clinical relevance for e.g. migraine. Others participate in symptoms of rare diseases like amyotrophic lateral sclerosis. Here we will focus on five of the neuropeptide receptors and their non-peptide ligands potentially or already successfully used as PET probes. Opioid receptors and neurotensin receptors are known to mediate analgesic actions. Bradykinin and calcitonin gene-related peptide (CGRP) receptors are known to be involved in the regulation of vascular tone and inflammatory responses, and neurokinin receptors play a role in the occurrence of pain perception in a rather indirect manner. Most experiences as PET tracers have been gathered with opioid receptor ligands and neurokinin receptor ligands. The most innovative fields revealed by the studies summarized in this report are the ligands of $\kappa$ opioid receptors and CGRP receptors for which a first PET tracer was presented recently.
\end{abstract}

\section{Keywords}

Neuropeptide Receptors, PET, Brain, Pain, Spinal Cord

\section{Introduction}

\subsection{Neuropeptides and Pain Syndroms}

The role of nociceptive and analgesic mechanisms is multifaceted and has great interest in receptor research

How to cite this paper: Pissarek, M. (2014) Neuropeptide Receptors in Pain Circuitries: Useful Targets for CNS Imaging with Non-Peptide Ligands Suitable for PET? World Journal of Neuroscience, 4, 353-383.

http://dx.doi.org/10.4236/wjns.2014.44040 
throughout many decades because of the high clinical relevance and disabling consequences of pain syndromes. Pain-inducing events include acute injuries or interventions, inflammatory (e.g. related to rheumatoid diseases) or vascular reactions (e.g. migraine; [1] [2]), chronic diseases and degenerative processes of unknown reasons responsible for e.g. amyotrophic lateral sclerosis (Lou-Gehring's disease, [3]-[6]) or due to endocrinological or metabolic processes like osteoporosis or diabetic neuropathy [7]. Furthermore, pain associated with cancer metastasis belongs to the main indications for the treatment with analgesics [8]. In chronic sensations, also central sensitizations responsible for peripheric allodynia or irritations of brain nerves for instance by herpes virus infections can play a role [1] [9]. On the other hand, endogenous compounds e.g. endorphins contribute to the interruption of pain circuitries in stress-induced analgesia [10]-[14].

Pain perception involves different kinds of receptors on various regulatory levels of the peripheral and central nervous systems. These can be located in primary sensory nerve endings, spinal cord, brainstem, thalamus, and different cortical regions like somatosensory and insular cortex as well as amygdala. The heterogeneous population of receptors is sensitive to a multitude of endogenous chemical stimuli. Alterations in ionic environment [15] belong to the signals activating first steps of pain sensitization in the periphery. Autacoids like prostanoids or the peptide bradykinin released from vascular cells induce an amplification of pain signals and support inflammatory processes. Monoamine or neuropeptide receptors act as attenuators or transformers of pain perception in spinal cord and cerebral structures.

A role of neuropeptide receptors in pain perception and relief has been discovered already very early, even if, like in the case of opioids as an extensively investigated transducer of analgesic signals, it was initially not known that the endogenous transmitters of these receptors were peptides and it took centuries until it became possible to identify and to characterize human neuropeptide receptors [16]-[18].

\subsection{G Protein-Coupled Receptors (GPCRs)—old and New Approaches to Signal Transduction}

In the brain which is devoid of nociceptive primary sensory units [9] nevertheless neuropeptide receptors contribute to signal pathways, inflammatory or vascular processes committed to creation and maintenance of painful alterations and sensations. In general, it is accepted that signaling of GPCR is accomplished via G proteins and the respective second messengers. Desensitization and internalization is recognized a consequence of the action of G protein-coupled receptor kinases (GRK) which induce through the binding of arrestin [19] the termination of receptor activation. Additionally, arrestin has been recognized during the last decades as a signal protein on its own which can associate with further regulatory proteins in multi protein complexes. Those can bias the conventional signaling pathways governed by $\mathrm{G}$ proteins in dependence on cell type and microenvironment [8] [20]-[23]. Ligand bias at 7-transmembrane receptors (7TMRs) responsible for a predominance either of signaling via $G$ proteins or of $\beta$-arrestin regulated pathways has been described for instance for neurokinin 1 and opioid receptors [24]-[26].

The increasing knowledge on promiscuous neuropeptide receptors linked to such additional key complexes obtained now a broader basis by a new understanding of the coexistence of two regulatory key proteins. Moreover, the rising number of 3D-crystal structures of GPCRs allow new insights into molecular dynamics of receptor ligand interactions. The $\mu$ opioid receptor was the first neuropeptide receptor for which a 3D structure was accomplished [27].

The scope of functional understanding of neuropeptide actions has been further extended by the discovery of direct receptor-receptor interactions suggesting heteromerization and mosaic formation between different subtypes and subfamilies of GPCRs as shown for opioid receptor subtypes [28] [29]. The boost in the characterization of 3D crystal structures since publication of the $\beta_{2}$-adrenergic receptor structure by Kobilka's group in 2007 [30] gave rise to new challenges to SPECT and PET methods and tracer development as valuable proofs of mathematical models of receptor-ligand interactions in vivo.

A number of opioid receptor heteromers has been described during the last few years for instance $\delta$ opioid receptor (DOR)-א opioid receptor(KOR) heteromers [31], DOR- $\mu$ opioid receptor (MOR) heteromers [32] [33] and MOR-KOR heteromer [34] but also heteromers with other receptor types e.g. an $\alpha 2 \mathrm{~A}$ adrenergic-MOR heteromer [28] [29] [35]-[37] guiding future research also to bivalent ligands which could give additional functional informations but also new therapeutic approaches.

Moreover, the knowledge on the role of transducer proteins has been extended during the last decades putting 
$\beta$-arrestins beside the $G$ proteins as similar important for different downstream signaling pathways contributing not only to termination of receptor responses but also to activation of chemotaxis, apoptosis and translational mechanisms [20].

\subsection{Blood-Brain-Barrier (BBB), Blood-Spinal-Cord Barrier (BSCB) and Potential Access by Emission Tomographic Imaging}

A further challenge for new nuclear medical in vivo methods is to contribute to the understanding of the interplay between spinal cord neuronal systems which can impede or enhance the signals conveyed to higher levels of the central nervous system [38].

In general, hitherto the use of peptide compounds for selective labeling of peptide receptors in the central nervous system is restricted. A recent review by Craik et al. [39] classified these substances in two main categories among which one comprises traditional "small molecules" ( $<500 \mathrm{Da}$; with oral bioavailability) and the other larger "biologics" (>5000 Da; need to be delivered via injection). Essential drawback of the small molecules is that they often show relatively low selectivity. The advantage is that with the prerequisite that the physicochemical features are suitable, the probability that the compound can cross the BBB is relatively good. The large molecules show low bioavailability, poor membrane permeability and metabolic instability. But at least the uptake via BBB or via the BSCB (which shows somewhat different properties [40] can be altered in special diseases like amyotrophic lateral sclerosis [6] or other diseases with deranged BSCB [41] and also in irritable bowel syndrome [42] [43].

The search for PET and SPECT suitable ligands of peptide receptors playing a role in pain perception was especially successful up to now for ligands at the opioid receptors which trigger the analgesic route and at CGRP (calcitonin gene-related peptide) receptors which mediate algesic effects by vascular interactions. Interesting compounds have been found also for tachikinins. However, a direct role of neurokinin receptors in central pain circuits could not be confirmed finally [44].

The tachykinin substance P became the pioneer peptide in the discovery of neuropeptide GPCR [45]-[47] but up to now opioid receptors are the most extensively discussed types of neuropeptide receptors targeted by developers of pain relieving drugs [13] [48]-[53].

Neurotensin receptors have been discovered with some delay as a further target of endogenous analgesic compounds [54]. Hitherto also for bradykinin, CGRP as well as for neuropeptide Y (NPY) and brain-derived neurotrophic factor (BDNF) is suggested a role in perception or mediation of painful stimuli [55] [56]. However, these peptides have been shown to influence inflammatory processes associated with pain rather directly affecting the cerebral microvasculature [57]. In the brain tissue special subtypes of opioid, neurotensin and neurokinin receptors as well as CGRP receptors have been detected in various regions in concentrations promising a sufficiently suitable target for the binding of potentially specific receptor antagonists and the development of PET and SPECT tracer [44] [58]-[60].

\section{Opioid Receptors}

\subsection{Opioids and Opioid Receptors}

Although actions of the plant opiates morphine and codeine have been well known and employed for many centuries, mammalian endogenous peptides acting at opioid receptors have been characterized for the first time in the seventies of the last century [61]. The knowledge on the two natural enkephalins (YGGFL: [Leu5] enkephalin; YGGFM: [Met5] enkephalin) discovered by the group of Kosterlitz provided also the amino terminal sequence which is common with further endorphins, neoendorphins ( $\alpha$-neoendorphin: YGGFLRKYPK); $\beta$-neoendorphin: YGGFLRKYP) and dynorphins but different from endomorphins (endomorphin A: YPWF, endomorphin B: YPFF) and nociceptin (FGGFTGARKSARKLADE). Nevertheless, the prepro-precursor proteins of enkephalins, dynorphins (dynorphin A: YGGFLRRIRPKLKWDNQ; dynorphin B: YGGFLRRQFKVVT) and of the 31 amino acid residue (a.a.r.) long ß-endorphin (YGGFMTSEKSQTPLVTLFKRAIIKRAYKKGE) are three different structures: preproenkephalin, preprodynorphin and ß-lipotropin (precursor of ß-endorphin) integrated into proopiomelanocortin which supplies also ACTH and MSH [61].

Four opioid receptors have been described [62]-[64] of the $\mu, \delta, \gamma$ and $\kappa$ types as well as the orphan receptor ORL (opioid receptor like receptor) [65]. All these receptors have been cloned already in the 1990ties [66]-[68]. 
Two subclasses of $\mu$ opioid receptors (MOR) have been described according to localization and three subtypes of $\kappa$ opioid receptors (KOR) have been proposed by computational modelling according to structure. However, only the $\kappa 1$ subtype has been identified experimentally up to now whereas a $\kappa 2$ subtype has been characterized as a heteromeric receptor formed by association of the $\delta 1$ and the $\kappa 1$ subtype [68].

$\mu$-Opioid receptors belong to the Class A GPCR ( $\gamma$ subfamily). It may transmit signals to different downstream regulatory pathways but predominantly to such mediated via $G_{i}$ proteins responsible for its analgesic effect. Following the activation the $\mu$ opioid receptor is phosphorylated and coupled to arrestin [69].

$\mu$-Opioid receptor sites are presented throughout peripheral nerves and have been identified in central nerve terminals of primary afferent neurons, peripheral sensory nerve fibers and dorsal root ganglia [70].

In the peripher nervous system (PNS) $\beta$-endorphins produce analgesia (particularly by binding to $\mu$-opioid receptors [52]. Binding of $\beta$-endorphin induces in the PNS the inhibition of the release of tachykinins, especially of substance $\mathrm{P}[70]$.

Opioids influence the membrane potential via different ion channels. They can keep the cell membrane in a hyperpolarized state via the inhibitory action on cAMP formation [71] but, moreover, they can stimulate G protein-coupled inwardly rectifying potassium (GIRK) channels resulting also in membrane hyperpolarization. Among the four GIRK channels the GIRK-II is important for opioid analgesia [70] [72].

The three classified subtypes of opioid receptors, $\mu, \delta$ and $\kappa$, mediate their actions via pertussis toxin sensitive $G$ proteins $\left(G_{i / o}\right.$ proteins) but also via pertussis toxin insensitive $G$ proteins like $G_{Z}, G_{14}$ and $G_{16}$, which stimulate GIRK and inhibit adenylate cyclase [70] [73]. Mobilization of intracellular $\mathrm{Ca}^{2+}$ via phospholipase $\mathrm{C}$ can be also mediated by $\mathrm{G}_{11}, \mathrm{G}_{14}$ and $\mathrm{G}_{16}$ protein.

Opioid receptors are located presynaptically where they regulate transmitter (e.g. dopamine) release and postsynaptically on interneurons and medium spiny neurons of the striatum [53].

The target receptor of substance $\mathrm{P}$, the neurokinin receptor, has been found in postsynaptic afferent terminals in laminae I, II and IX of the spinal cord [38] [70]. CGRP can facilitate the activity of substance P in the dorsal horn of the spinal grey matter and glutamate is known to be involved in several steps of nociceptive transmission which can be modulated by the action of opioids.

The $\sigma$ receptor which has been originally presumed to be a further subclass of opioid receptors and also a phencyclidine (PCP) binding site could be characterized meanwhile as a binding site of the N-methyl-D-aspartate (NMDA) receptor [74]. This binding site is now accounted to the group of "receptor chaperons" [74] [75]. It has been demonstrated autoradiographically that opiate receptors and PCP binding site have different localizations [76] [77]. The $\sigma-1$ receptor of the different species are highly homologeous, however, the protein shows no homology with other mammalian proteins but 30\% homology with the yeast gene encoding C7-C8 sterolisomerase [78].

The largest densities of $\mu$ opioid receptors have been found in the brains of rodents (range of 120 - 240 fmol/mg) [79] (Table 1).

In general, the largest density of opioid receptors in the spinal cord has been observed in the dorsal horn (lamina I and II). However, the autoradiographic analysis by different authors revealed different predominance of the receptor subtypes in this region. An early work by Czlonkowski et al. [80] ranked the abundance of the receptor subtypes in human spinal cord with highest frequency of $\kappa$ binding sites ( $41 \%-59 \%$ of the opioid receptors) in this region. A somewhat lower contribution was identified for the $\mu$ opioid subtype with $33 \%-49 \%$, and $\delta$-re- ceptors were identified in $8 \%-15 \%$ of the opioid binding sites. Besse et al. [81] reported some years later about a predominance of $\mu$-opioid receptors (70\% of the opioid receptors in the rat spinal cord). The $\delta$ subtype has been found at the second position providing $24 \%$ of the total number of opioid receptors and $6 \%$ were attributed to the $\kappa$-subtype [70]. In the human spinal cord Faull et al. [82] found a density of opioid binding sites in the range between 10 and $33 \mathrm{fmol} / \mathrm{mg}$. Finally, the data reveal some species differences. However, there is no doubt, that in humans KORs and especially theк1 receptorplays the most pivotal role in the mediation of pain perception, and transmission of the respective signals [38].

Supraspinally, MORs have been found in the amygdala, nucleus accumbens, striatum, thalamus, hypothalamus, periaqueductal grey, reticular formation, locus coeruleus and rostral ventromedial medulla. In the thalamus $\mu$ opioid receptors have been described in the medial nuclei which relay the signal input from the spinothalamic tract to the cingulate cortex and limbic parts of the brain [53] [70].

In the human brain opioid receptors achieve relatively low densities compared to the rodent brain [83] (see Table 1) with moderate differences between $\mu, \delta$ and $\kappa$ subtypes and a tendency to larger densities of KORs. 
Table 1. Densities of neuropeptide (pain) receptors in brain tissues of different species: Data obtained by means of autoradiographic and membrane binding studies (rodent, monkey, human) available in the literature (in fmol/mg protein; or *** in $\mathrm{fmol} / \mathrm{mg}$ wt. weight) Abbreviations: DAMGO: [D-Ala ${ }^{2}$,MePhe,Gly(ol) ${ }^{5}$ ]enkephalin;DELT-I $\left[{ }^{3} \mathrm{H}\right]-\left[\mathrm{D}-\mathrm{Ala2}\right.$ ]deltorphinI; $\left[{ }^{3} \mathrm{H}\right]$ DAGO: Tyr-D-Ala-Gly-(N-Me)Phe-Gly-ol, [ $\left.{ }^{3} \mathrm{H}\right] \mathrm{DTLET}$ : $\left[{ }^{3} \mathrm{H}\right] \mathrm{Tyr}-\mathrm{D}-\mathrm{Thr}-\mathrm{Gly}-\mathrm{Phe}-\mathrm{Leu}-\mathrm{Thr}$; [ $\left.{ }^{125} \mathrm{I}\right] \mathrm{BP}-\mathrm{SP}$ : Bolton HunterSubstance P; $\left[{ }^{125} \mathrm{I}\right]$ NKA: $\left[{ }^{125} \mathrm{I}\right]$ Iodohistidyl-Neurokinin A; $\left[{ }^{125} \mathrm{I}\right]$ BP-ED:[ $\left.{ }^{125} \mathrm{I}\right]$ Bolton-Hunter-eledoisin.

\begin{tabular}{|c|c|c|c|c|c|c|}
\hline \multicolumn{7}{|c|}{ Densities of neuropeptide receptors in brain tissues of different species } \\
\hline Receptor & $\begin{array}{l}\text { Density } \\
\text { in } \mathrm{fmol} / \mathrm{mg}\end{array}$ & Species & Region & Method & Ligand & References \\
\hline \multirow{3}{*}{$\mu$ opioid } & 120 and 240 & Rat & Brain homogenate & Membrane binding & $\beta_{\mathrm{h}}-\left[{ }^{3} \mathrm{H}\right]$ endorphin & [79] \\
\hline & $9.2-137$ & Mice & $\begin{array}{l}\text { Striatum, thalamus, red } \\
\text { nuclei }\end{array}$ & Autoradiography & {$\left[{ }^{3} \mathrm{H}\right] \mathrm{DAMGO}$} & [84] \\
\hline & $8.1-38.1$ & Human & Cortex & Autoradiography & {$\left[{ }^{3} \mathrm{H}\right] \mathrm{DAGO}$} & [83] \\
\hline \multirow{2}{*}{$\delta$ opioid } & $14-86$ & Mice & $\begin{array}{l}\text { Frontal+ } \\
\text { cingulate cortex }\end{array}$ & Autoradiography & {$\left[{ }^{3} \mathrm{H}\right]$ DELTI } & [84] \\
\hline & $27.3-56.2$ & Human & Cortex & Autoradiography & {$\left[{ }^{3} \mathrm{H}\right] \mathrm{DSLET}$} & [83] \\
\hline$\kappa 1$ opioid & $2.9-84.6$ & Mice & $\begin{array}{l}\text { Striatum, accumbens, } \\
\text { hypothalamus }\end{array}$ & Autoradiography & {$\left[{ }^{3} \mathrm{H}\right] \mathrm{Cl}-977$} & [84] \\
\hline \multirow[t]{2}{*}{$\kappa$ opioid } & $6.6-120$ & Mice & $\begin{array}{l}\text { Striatum, temporal cortex, } \\
\text { accumbens, hypothalamus }\end{array}$ & Autoradiography & {$\left[{ }^{3} \mathrm{H}\right]$ bremazocine } & [84] \\
\hline & $15.0-111.8$ & Human & Cortex & Autoradiography & {$\left[{ }^{3} \mathrm{H}\right]$ bremazocine ${ }^{*}$} & [83] \\
\hline $\begin{array}{c}\text { Opioid (total: } 41 \%- \\
59 \% \kappa ; 33 \%-49 \% \mu \text {; } \\
8 \%-15 \% \delta \text { ) }\end{array}$ & $10-33$ & Human & $\begin{array}{l}\text { Spinal cord (dorsal horn: } \\
\text { Lamina I-III; lissauer tract) }\end{array}$ & Autoradiography & Diprenorphine & [82] \\
\hline $\begin{array}{l}\text { Neurotensin } \\
\text { NTS1/NTS2 }\end{array}$ & 527 & $\begin{array}{c}\text { Sprague } \\
\text { Dawley rats }\end{array}$ & $\begin{array}{l}\text { Brain without } \\
\text { cerebellum }\end{array}$ & $\begin{array}{l}\text { Membrane } \\
\text { binding }\end{array}$ & $\begin{array}{l}\text { SR142948A in absence } \\
\text { of } 10 \mu \mathrm{M} \text { levocabastine }\end{array}$ & [112] \\
\hline NTS1 & 104 & $\begin{array}{l}\text { Sprague } \\
\text { Dawley rat }\end{array}$ & “ & $\begin{array}{l}\text { Membrane } \\
\text { binding }\end{array}$ & $\begin{array}{c}\text { SR142948 in Presence } \\
\text { of levocabastine }\end{array}$ & [112] \\
\hline NTS2 & 422 & $\begin{array}{l}\text { Sprague } \\
\text { Dawley rat }\end{array}$ & “ & “ & $\begin{array}{l}\text { SR142948 in Presence } \\
\text { of levocabastine }\end{array}$ & [112] \\
\hline CGRP & $214-250$ & Rat & Hypothalamus & $\begin{array}{l}\text { Membrane } \\
\text { binding }\end{array}$ & {$\left[{ }^{125} \mathrm{I}\right] \mathrm{CGRP}$} & $\begin{array}{l}{[113]} \\
{[114]}\end{array}$ \\
\hline \multirow[t]{2}{*}{$\begin{array}{l}\text { Bradykinin } \\
\text { B2 }\end{array}$} & $0.9-1.9$ & Rat & $\begin{array}{l}\text { NTS/area postrema, spinal } \\
\text { trigeminal nucleus, vagal } \\
\text { dorsal motor nucleus } \\
\text { Spinal cord }\end{array}$ & Autoradiography & {$\left[{ }^{125} \mathrm{I}_{-}\right.$Tyr $^{0}$-Bradykinin } & [115] \\
\hline & $1.8-4.5$ & Rat & Spinal cord & Autoradiography & {$\left[{ }^{125} \mathrm{I} \mathrm{Tyr}^{8}\right.$-Bradykinin } & [116] \\
\hline \multirow{5}{*}{ NK1 } & 94 & Gerbil & Cortex & & & \\
\hline & 607 & Gerbil & Striatum & Autoradiography & {$\left[{ }^{3} \mathrm{H}\right] \mathrm{GR} 205171$} & [44] \\
\hline & $59-74$ & Human & Cortex & & & \\
\hline & $318-432$ & Human & Striatum & & & \\
\hline & $8.67-13.24^{* * *}$ & Rat & Spinal cord & Autoradiography & {$\left[{ }^{125} \mathrm{I}\right] \mathrm{BH}-\mathrm{SP}$} & [203] \\
\hline \multirow[t]{2}{*}{ NK2 } & 7.3 & Rat & Hippocampus & $\begin{array}{c}\text { Membrane } \\
\text { binding, } \\
\text { Autoradiography }\end{array}$ & {$\left[{ }^{125} \mathrm{I}\right] \mathrm{NKA}$} & [117] \\
\hline & $1.65-2.55^{* * *}$ & Rat & Spinal cord & Autoradiography & “ & [203] \\
\hline \multirow{2}{*}{ NK3 } & 31.2 & Rat & Cortex & Autoradiography & {$\left[{ }^{3} \mathrm{H}\right]$ Senktide } & [118] \\
\hline & $2.53-3.08^{* * *}$ & Rat & Spinal cord & Autoradiography & {$\left[{ }^{125} \mathrm{I}\right] \mathrm{BP}-\mathrm{ED}$} & [203] \\
\hline
\end{tabular}

Enkephalin mediates via $\delta$ opioid sites inhibition of GABA release. Dynorphin binds $\kappa$ opioid sites and inhibits glutamate release in the globus pallidus interna from subthalamic projections [53].

$\beta$ endorphins act via presynaptic $\mu$ opioid receptors mediating inhibition of the release of GABA, which results in excess production of dopamine [53].

\subsection{Opioid Receptor Ligands}

Autoradiographic analysis revealing the receptor distribution in the brain and spinal cord as summarized in Table 1 has been performed using tritium labelled peptide agonists like DAMGO (MOR) [70], DELTI (DOR) 
[84] and non-peptide agonists like bremazocine (KOR) [84].

Furthermore, highly specific antagonists for the $\mu$-opioid receptor (funaltrexamine [85] [86]); for the $\delta$-receptor (naloxonazine; [87]) and the KOR1 receptor (nor-binaltorphimine (4; Nor-BNI) [88]) were used. Autoradiographic analysis confirmed that the most frequent types of opioid receptors in the dorsal horn of the spinal cord are $\mu$ and $\kappa$ receptors (with some species differences) while in the brain special regions achieved large densities of $\mu, \delta$, or $\kappa$ receptors [82]-[84]. PET ligands have been established up to now especially for $\mu$ and $\kappa$ receptors. $\left[{ }^{11} \mathrm{C}\right]$ carfentanil (1) (Figure 1 and Table 2) (MOR agonist) [89]-[91], $\left[{ }^{11} \mathrm{C}\right]$ Diprenorphine $(\delta$ opioid receptor antagonist) are well known as well as $\left[{ }^{18} \mathrm{~F}\right]$ cyclofoxy (2) (Figure 1 and Table 2), $\left[{ }^{18} \mathrm{~F}\right]$ acetylcyclofoxy [92] [94]-[96] and $\left[{ }^{11} \mathrm{C}\right]$ buprenorphine [97] [98] as nonselective ligands. $\left[{ }^{11} \mathrm{C}\right] \mathrm{GR} 103545$ (3) (Figure 2 and Table 2) is the R-enantiomer of the racemic $\left[{ }^{11} \mathrm{C}\right]$ GR89696 binding at $\kappa 1$ receptors [98]. Carfentanil, used in veterinary medicine, was one of the first PET tracers for labelling of a neuropeptide GPCR and had been employed also for establishing and evaluating of different compartment models [90] [99]-[101].

The KOR antagonist 5-guanidinonaltrindole (GNTI) provides a 5 fold higher affinity than the prototypical agonist Nor-BNI and an order of magnitude greater selectivity. However, it belongs to the compounds with long acting properties which can be difficulty evaluated for their structur activity relelationships [88] [102].

GR 103545 (3; Figure 2) has a high affinity to $\kappa$ receptors close to that of GNTI (for instance IC $_{50} 18 \mathrm{pM}$ in vitro/rabbit vas deferens or $0.22 \mathrm{nM}$ in rhesus monkey brain homogenate) as well as good brain penetration [103], however, poor selectivity versus the $\mu$ - and $\delta$-receptor subtypes. Moreover, an intrinsic agonist activity and significant side effects on blood flow and further circulation parameters have been reported for GR 103545.

Thomas et al. presented in 2001 a first $\kappa$ opioid receptor antagonist (JDTic) (5) (Figure 2 and Table 2) using a not opiate compound as lead structure [104] and disclosed two years later a further derivative of JDTic with an additional methyl group at the N-position of tetrahydroisoquinoline ring (MeJDTic; (6) Figure 2 and Table 2; [105]). Recently, Munro et al. [106] reported delayed but long-time persisting action of JDTIc which suggests special pharmacokinetic and pharmacodynamics properties. The authors conclude that the delay is due to an entrapment of JDTic in cellular compartments e.g. lysosomes. Poisnel et al. published in 2008 an improved procedure for radiolabelling of MeJDTic by means of $\left[{ }^{11} \mathrm{C}\right]$ methyl triflate and $\left[{ }^{11} \mathrm{C}\right]$ methyl iodide achieving yields of $78 \%-98 \%$ and $75 \%-82 \%$, respectively [98]. Specific activities between 1.48 and $4.44 \mathrm{GBq} / \mu \mathrm{mol}$ were available at the end of the synthesis [98]. The compound showed with a $\log \mathrm{P}$ of 2.7 a good lipophilicity and high affinity at the $\kappa$ opioid receptor $\left(\mathrm{K}_{\mathrm{i}} 0.053 \mathrm{nM}\right)$, however, only a rather low brain uptake of $0.15 \% \mathrm{ID} / \mathrm{g} 5$ min post injection. This low brain uptake is attributed to the fact that a large part of the injected radiotracer remains in the periphery e.g. bound to the lungs $(12 \%$ - 30\% ID/g), in the kidney $(12 \%-30 \%)$ as well as in the liver (15\% ID/g) [98].

First experiments with the novel $\kappa$ opioid receptor antagonist $\left[{ }^{11} \mathrm{C}\right] \mathrm{LY} 2795050$ (8) $\left(\mathrm{K}_{\mathrm{i}} 0.72 \mathrm{nM}\right)$ (Figure 2) resulted in a markedly lower $\mathrm{B}_{\max } / \mathrm{K}_{\mathrm{d}}$ ratio than expected from in vitro experiments but demonstrated good selective binding at KORs which could be reduced by the selective KOR antagonist LY245302 (7) during in vivo experiments in monkeys [107].

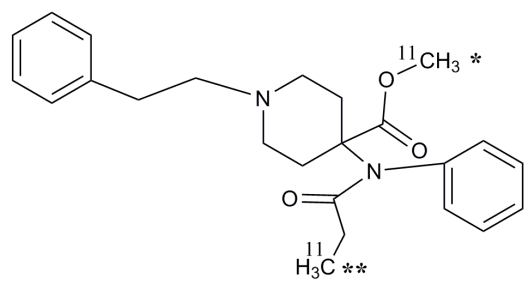

1

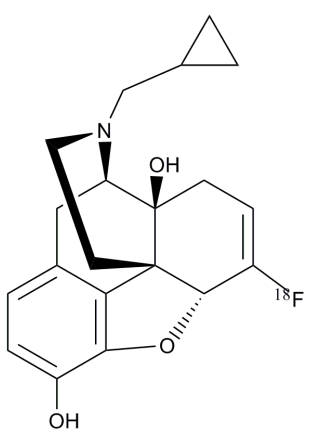

2

Figure 1. $\mu$-opioid receptor ligands:1) Methyl-1-phenethyl-4-(N-phenylpropionamido) piperidine-4-carboxylate 2) (4R,4aS,7aR, 12bS)-3-(cyclopropylmethyl)-7fluoro-1,2,3,4,5,7a-hexahydro-4aH-4,12-methanobenzofuro [3,2-e] isoquinoline-4a, 9-diol. Asterisks indicated two different positions of labelling which have been reported. 
Table 2. Partition coefficients $\log \mathrm{P}$ and $\log \mathrm{D}$ as well as molecular weights for selected neuropeptide receptor ligands. Bold and parenthesized numbers correspond to the number of the respective formula in the figures (ACD/ChemSketch* and Scifinder software was the source of some of the data).

\begin{tabular}{|c|c|c|c|c|c|c|}
\hline \multicolumn{7}{|c|}{ Partition coefficients $\log P$ and $\log D$ as well as molecular weights for selected neuropeptide receptor ligands } \\
\hline Compound & Peptide receptor & CAS registry & MW & $\log P$ & $\log D$ & Reference \\
\hline Carfentanil (1) & MOR & $59708-52-0$ & 394.51 & 3.68 & 3.13 & [89] \\
\hline Cyclofoxy (2) & MOR, KOR & 103223-57-0 & 345.41 & 1.64 & 1.30 & [92] [93] \\
\hline GNTI & KOR & 219655-56-8 & 471.55 & 0.8 & -2.41 & [102] \\
\hline MeJDTic (5) & KOR & - & 481.67 & $3.65^{*}, 2.7$ & & [104] \\
\hline JDTic (6) & KOR & 785835-79-2 & 467.64 & $3.26^{*}$ & & [105] \\
\hline SR 142948 (9) & NTS1 (NTS2) & 184162-64-9 & 685.85 & 7.22 & 4.72 & [136] \\
\hline SR 48692 (10) & NTS1 (NTS2) & 146362-70-1 & 587.07 & 5.7 & 5.2 & [135] \\
\hline $\begin{array}{c}\text { Olcegepant } \\
\text { (BIBN4069BS) (11) }\end{array}$ & CGRP & 204697-65-4 & 869.65 & 3.246 & 0.40 & [156] \\
\hline BMS-694153 (12) & CGRP & 1050381-35-5 & 644.78 & 3.081 & 0.86 & [158] \\
\hline MK-4232 (14) & CGRP & 1263291 & 585.64 & 3.38 & & [153] \\
\hline MK3207 (15) & CGRP & 957118-49-9 & 557.62 & 0.202 & -0.12 & [159] \\
\hline MK0974 (Telcagepant) (16) & CGRP & 781649-09-0 & 566.52 & 1.3 & 1.3 & [150] \\
\hline CGRPA2 (17) & CGRP & - & 587.65 & $\begin{array}{c}3.43^{*} \\
\text { Non-brain penetrant }\end{array}$ & & [153] \\
\hline LF 160687 (Anatibant) (20) & B2 & 209733-45-9 & 711.66 & 3.38 & 1.39 & [176] \\
\hline L 742,694 (21) & NK1 & 159706-39-5 & 502.41 & 4.78 & 4.72 & [224] \\
\hline CP-96345 (22) & NK1 & $132746-60-2$ & 412.57 & 5.739 & 2.89 & [213] \\
\hline $\begin{array}{c}\text { MK } 0869 \text { (Aprepitant) (25) } \\
\text { L 754,030 } \\
\text { (metabolit of MK0869) }\end{array}$ & NK1 & $\begin{array}{l}170729-80-3 \\
17012980-3\end{array}$ & $\begin{array}{l}534.43 \\
683.76\end{array}$ & $\begin{array}{l}4.99 \\
3.85^{*} \\
-5.5\end{array}$ & $\begin{array}{r}4.93 \\
-7.51\end{array}$ & [225] \\
\hline L 758,298 (Fosaprepitant) & NK1 & 172673-20-0 & 614.41 & 1.97 & -2.09 & [226] \\
\hline SPA-RQ (26) & NK1 & 262598-99-2 & 450.43 & $3.23^{*}$ & & [232] \\
\hline SR 48968 (Saredutant) & NK2 & $142001-63-6$ & 552.5 & 3.44 & 2.45 & [233] \\
\hline SR 142.803 (Osanetant) & NK3 & 160492-56-8 & 606.62 & 6.21 & 5.24 & [237] \\
\hline SB223412 (Talnetant) & NK3 & 174636-32-9 & 382.45 & 5.8 & 4.99 & [238] \\
\hline TAK 637 & NK3 & 217185-75-6 & 573.53 & 7.03 & 7.03 & [239] \\
\hline
\end{tabular}

\section{Neurotensin Receptors}

\subsection{Neurotensin and Neurotensin Receptors}

The neurotensin system is widely distributed in the CNS and peripheral tissues [108] [109]. It accounts for an essential part of the non-opioid stress-induced analgesia and is probably involved into further analgesic circuitries.

The 13 a.a.r. peptide neurotensin (ELYENKPRRPYIL) is a neurotransmitter as well as neuromodulator in the brain and a paracrine or circulating hormone in the periphery [110] [111]. Neurotensin is facilitating pain if applied in low doses (0.03 pM - $0.03 \mathrm{nM}$; [119] [120]) to the rostral ventromedial medulla (RVM) [121] but revealed an analgesic effect at higher dosage [10].

The peptide has been shown to modulate dopaminergic transmission in the midbrain [122]. It contributes to nociception, hypothermia and control of anterior pituitary hormone release. Two subtypes of 7TMD neurotensin receptors are known: NTS1 (NTRH; a high affinity receptor which binds also levocabastine (a histamine H1 antagonist but with low affinity) and NTS2 (NTRL; low affinity receptor to neurotensin, which binds also levocabastine but with higher affinity). The NTS1subtype was observed predominantly in humans, rabbits and guinea pigs whereas NTS2 was found also in adult rat and mouse brain [113] [123] [124]. The histamine antagonist 


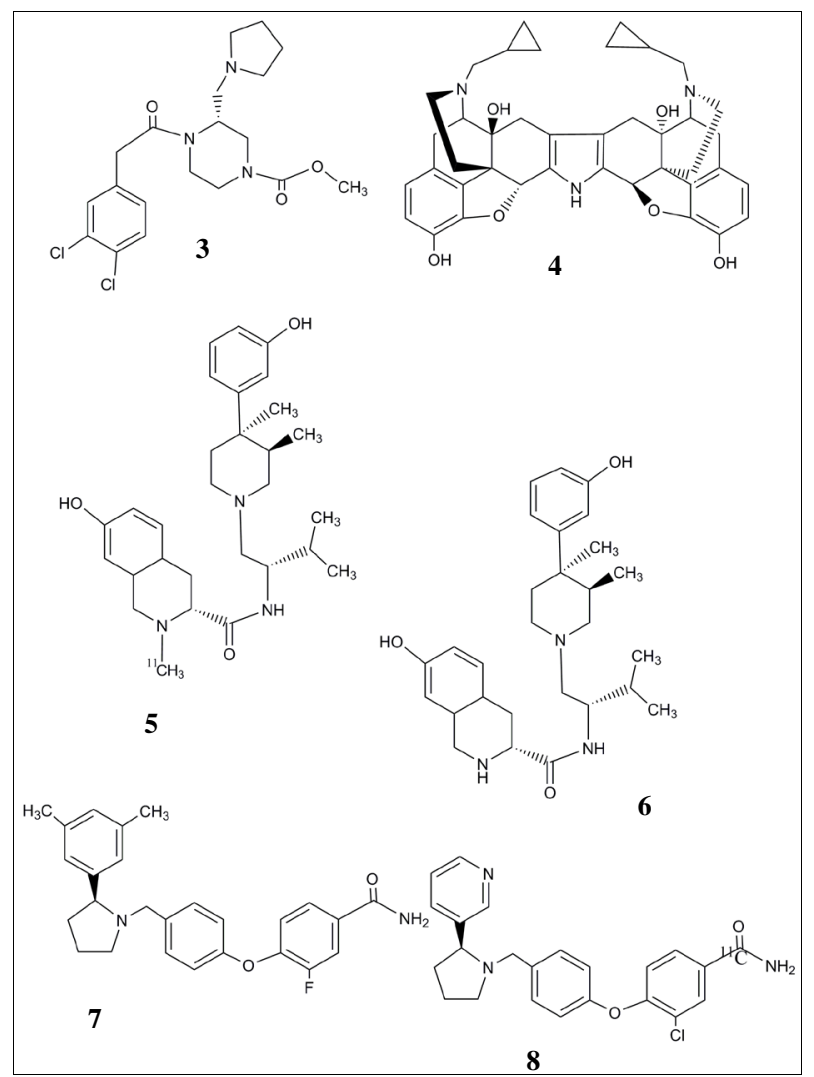

Figure 2. א-opioid receptor ligands:3) Methyl-(R)-4-(2-(3,4-dichlorophenyl) 3(pyrrolidin1-ylmethyl) piperazine-1-carboxylate 4) 17, 17'-(dicyclopropylmethyl)- 6,6',7,7'-6,6-imino-7,7'binorphan-3,4’14, 14'-tetrol 5) (3R)-7-hydroxy- N-((S)-1-((3R,4 R)-4-(3-hydroxyphenyl)-3,4dimethyl piperidin-1-yl)-3-methylbutan-2yl)-2-methyl-1,2,3,4,4a,8a-hexahydroisoquinoline-3carboxamide 6) (3R)-7-hydroxy-N-((S)-1-((3R,4 R)-4-(3-hydroxy-phenyl)-3,4-dimethylpiperidin-1-yl)-(3-methylbutan-2yl)-1,2,3,4,4a,8a-hexahydroiso- quinoline- 3-carboxamide 7) (S)-3chloro-4-(4-((2-(3,5-dimethyl-phenyl) pyrrolidin-1-yl)methyl)phenoxy)-3-fluorobenzamide 8) (S)-3-chloro-4-(4-((2-pyridin-3-yl)pyrrolidin-1-yl)methyl)phenoxy)benzamide.

levocabastine has been shown to act as an agonist at the NTS receptors in mice, and as an antagonist in humans [125].

The NT3 receptor (NTS3) is a $100 \mathrm{kDa}$ protein with a single transmembrane domain containing a cysteine rich domain and belongs to the Vps10p-D receptor family (type I transmembrane receptor family) comprising the sortilin receptor (NTR3), SorCS1, SorCS2, SorCS3 and SorLA. It contributes to molecule sorting between cell surface and intracellular compartments [110] [126]-[128]. However, a contribution of the NTS3 receptor to the action of the other neurotensin receptor subtypes, especially of NTS1 is also possible [129]. Eventually, NTR4/SorLA is a further receptor proposed [54].

Neurotensin mediates, especially acting at its neurotensin 1 receptor (NTS1), via multiple oncogenic signaling pathways like PKC/ERK and AKT, several effects in the development of cancer, which include cell proliferation, migration, invasive growth and neoangiogenesis [130].

NTS3 is suggested to mediate NT effects on microglial migration, cytokine expression and proliferation of cancer cells [110] [119].

However, analgesic effects by neurotensin are not mediated under any condition at the receptors NTS1 and NTS2. It has been revealed that NT acts agonistic in NTS1 mediated pathways NT but at NTS2 receptors neurotensin can induce agonistic and antagonistic activities [110] also dependent from the animal species. Although the NTS2 receptor can be associated with several G proteins allowing the mediation of a diversity of G protein dependent effects, it was for long time not clear whether this subtype of the receptor has really any key function in the body and in which way $\mathrm{G}$ proteins could play a role in its actions [110]. 
Meanwhile has been demonstrated that NTS2 plays a particular role in the stimulation of corticotropin releasing factor. At the level of the lumbar spinal cord, a participation of this receptor subtype in disinhibition of descending pain control pathways has been suggested [14].

\subsection{Neurotensin Receptor Ligands}

Whereas recently some efforts were made to develop peptide analogs with specific binding to neurotensin receptors [131] [132] as well as hybride peptide tracers [133] [134], there are only few non-peptide lead structures for high affinity and specific neurotensin receptor ligands available.

Especially two neurotensin-receptor ligands are known since relatively long period of time. These are the adamantine derivatives SR 142948A (9) (Figure 3) and SR 48692 (10) (Figure 3). SR 48692 was the first high affinity and selective non-peptide neurotensin receptor antagonist discovered by Gully et al. [135]. This orally active compound showed higher affinity to NT1 receptors than neurotensin. SR 48692 had in guinea pig brain homogenates an $\mathrm{IC}_{50}$ of $0.99 \mathrm{nM}$ vs $2.8 \mathrm{nM}$ for neurotensin (for inhibition of ${ }^{125}$ I-neurotensin binding in coronal sections of midbrain). In turn the $\mathrm{IC}_{50}$ in rat brain homogenates was higher ( IC $_{50} 82 \mathrm{nM}$ vs. $3.2 \mathrm{nM}$ for neurotensin) and the Hill coefficient confirmed that there is not only one binding site. The binding affinities of SR 48692 for newborn mouse and human brain as well as for adult brains of the same species were between these values (IC $5013.7 \mathrm{nM}, 17.8 \mathrm{nM}$ (newborn) and 34.8 and $8.7 \mathrm{nM}$ (adult), respectively) [135]. Autoradiographic studies in guinea pig identified moderate densities of neurotensin receptors in substantia nigra pars compacta, ventral tegmental area as well as high densities of these receptors in the cortical nucleus of the amygdala, the pyramidal layer of the hippocampal formation and granular cells of the gyrus dentatus. SR 48692 could displace neurotensin from all these structures. SR142948A disclosed some years after SR 48692 [136] binds also to NT1 and NT2 receptors. However, in contrast to SR48692 it could block hypothermia and analgesia induced by central application of neurotensin [112] [136]. Saturation studies in rat brain membranes revealed a single class of high affinity binding sites $\left(\mathrm{K}_{\mathrm{d}} 3.48 \mathrm{nM}\right)$ and $\mathrm{K}_{\mathrm{i}}$ values for displacement of neurotensin of $5.0 \mathrm{nM}$. The $\mathrm{K}_{\mathrm{i}}$ value in the competition experiment with neurotensin was $32.8 \mathrm{nM}$ for the displacement of SR 142948A and in the competition by SR48692 $\mathrm{K}_{\mathrm{i}}$ was $123.6 \mathrm{nM}$ [112]. The separate analysis of NT1 and NT2 receptor $\left(\mathrm{K}_{\mathrm{d}} 8.5 \mathrm{nM}\right)$ density resulted in $B_{\max }$ values of $104 \mathrm{fmol} / \mathrm{mg}$ protein and $422 \mathrm{fmol} / \mathrm{mg}$ protein [112] (Table 1).

\section{Calcitonin Gene-Related Receptors}

\subsection{Calcitonin Gene-Related Peptide and CGRP Receptor}

The 37 a.a.r. peptide CGRP (ACDTATCVTHRLAGLLSRSGGVVKNNFVPTNVGSKAF) can act as potent vasodilator as well as a neuromodulator in the brain. This peptide is potentially involved in the occurrence of migraine which affects $12 \%$ of the society in western countries [2] [137].

Several locations of CGRP release have been identified which contribute to occurrence and maintenance of migraine attacks (primary sensory neurons of the trigeminal ganglion, dorsal spinal cord and perivascular nerve endings but also the smooth muscle layers of intracranial blood vessels) [60] [138] [139]. The intracranial CGRP
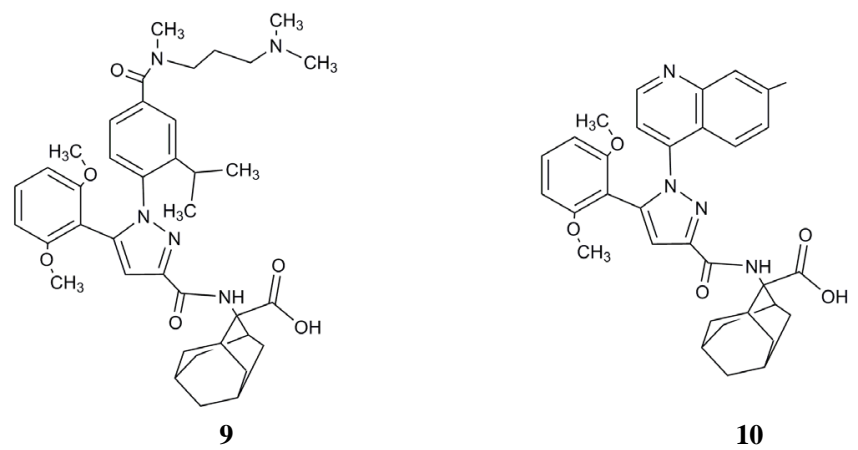

10

Figure 3. Neurotensin receptor ligands: 9) (2-\{[5[2,6-dimethoxyphenyl)-1-(4-(N-(3-dimethyl-aminopropyl) N-methyl-carbamoyl-2-isopropylphenyl)-1H-pyrazol-3-carbonyl] amino] adamantane-2 carboxylic acid 10) (2-\{[1-(7-chloro-quinolin-4-yl)-5-(2,6-dimethoxypheyl)-1H-pyrazole-3-carbonyl] amino $\}$ adamantane-2-carboxylic acid. 
fibres have their origin in the trigeminal ganglion [140] [141].

CGRP receptors have been reported to be involved in pain transmission and inflammation [57] [142]. The CGRP receptor is a $G$ protein-coupled receptor which is comprised of a multimeric complex including the calcitonin receptor like receptor (orphan receptor CLR; member of secretin family/class B) [143], as well as an accessory protein (receptor activity modifying membrane protein 1; RAMP 1) which includes a 148 a.a.r peptide with a single transmembrane domain [144] [145] and an intracellular protein (receptor component protein; RCP) [140] [146]. Combinations of RAMP 2 and 3 subtypes with CLR which can bind also CGRP but with lower affinity and preferring adrenomedullin (AM) (AM > $\alpha$ CGRP > amylin > calcitonin; [147]) form the adrenomedullin receptors 1 and 2 (AM1 and AM2). Combinations of RAMP 1 - 3 with the calcitonin receptor (CTR) result in the amylin receptors (AMY) 1 - 3 [143] [148]. AM, CT and AMY receptors are of importance for the characterization of selectivity CGRP ligands.

Neural cells produce via alternative splicing two different 37 a.a.r. CGRPs: $\alpha$ CGRP (outside the central nervous system in TRPV1-expressing and capsaicin sensitive primary sensory neurons) and ßCGRP (not encoded by calcitonin gene and found in intrinsic neurons of the gut) [143] [149].

The major task of CGRP seems to be dilation of arterial vessels in a NO independent manner by direct action of cAMP on the smooth muscle [151]. CGRP antagonists have been shown to inhibit vasodilation as well as neural transmission [152].

CGRP receptors could be shown by PET imaging particularly in cerebellum and brainstem [143] [153]. The structural units CLR and RAMP1 have been found in middle meningeal, middle cerebral pial and superficial temporal arteries [140] [154].

The role of these CNS receptors in pain transmission (especially in migraine attacks) is yet not fully understood [153]. However, some antagonists of the CGRP receptor have been shown also in clinical trials to contribute to pain relief in migraineurs. Moreover, functional activation of cerebellar and brainstem regions could be observed by means of PET [140] [155]. Mismatch in the recovery of brainstem and cerebellar regions resulted in the presumption that an imbalance between brain stem nuclei regulating antinociception and vascular control could be the basis of the pathogenesis of migraine [153].

\subsection{CGRP Receptor Ligands}

CGRP receptor ligands have been already used in clinical studies with some success in relief of migraine associated symptoms. These include the antagonists olcegepant (BIBN4096BS, [156] (11) (Figure 4 and Table 2), MK 3207 (15) [60] (Figure 5 and Table 2) telcagepant (MK-0974) (16) (Figure 5 and Table 2), and BI 4370TA [157]. Olcegepant was one of the first CGRP antagonists shown to be effective in the suppression of CGRP induced pain and to inhibit vasodilation without cardiovascular side effects as known for triptans which belong commonly to the medication of migraineurs if they are free of cardiovascular diseases. However, not all species among laboratory animals can reflect the distribution of CGRP receptors in humans. Only marmoset and rhesus monkeys have been found to show a human-like CGRP receptor pharmacology [154] [158]. The human CGRP receptor contains in its heteromeric RAMP1 structure a specific a.a.r. (W74) suggested to be of key importance for the characteristic binding properties of hCGRP [156]. The difference of the amino acid in this position has been made responsible for low homology between the RAMP-1 proteins of primates and humans and that of rats (with Lys74; [152]. Olcegepant has been developed from a dipeptide mimetic R1-(3,5-dibromo-Tyr)LYS-R2. As revealed by analysis of the structure-activity-relationships, similar structures were achieved when the N-terminal functionality was aromatic and was separated from the 3,5-dibromo-Tyr moiety, whereas for the C-terminal region a rigid negative polarizing group linked to a pyridine was favorable [149] [152]. These developments resulted in a high affinity CGRP antagonist $\left(\mathrm{IC}_{50}, 0.014 \mathrm{nM}\right)$ which could inhibit neurogenic vasodilation in a surrogate animal model of migraine. The substance had a 100fold higher selectivity for hCGRP compared to the rat receptor [149] [152] [154]. The agonist CGRP2 (17) (Figure 5 and Table 2) differs only in few structural features from olcegepant while SB 273779 (13) (Figure 4) [152] avoids the high species selectivity but also the high affinity of these substances.

Some novel compounds with moderate or high affinity and good oral bioavailability have been proposed to be potential therapeutics of migraine. These include for instance dihydrospiro-indene-pyrrolo-pyridins, e.g. MK8825 [160] or MK3207 [60]. MK 3207 showed in LLC-PK1 pig kidney epithelial cells a $\mathrm{K}_{\mathrm{i}}$ of $0.021 \mathrm{nM}$ but is a substrate of the P-gp transporter $(\mathrm{P}-\mathrm{gp}=25)$ [60]. MK 8825 showed a $\mathrm{K}_{\mathrm{i}}$ of 0.052 (displacement of 
<smiles>NCCCC[C@H](NC(=O)[C@H](Cc1cc(Br)c(O)c(Br)c1)NC(=O)N1CCC(N2Cc3ccccc3NC2=O)CC1)C(=O)N1CCN(c2ccncc2)CC1</smiles><smiles>Cc1cc(C[C@H](NC(=O)N2CCC(N3Cc4cccc(F)c4NC3=O)CC2)C(=O)N2CCC(N3CCCCC3)CC2)cc2cn[nH]c12</smiles><smiles>Cc1ccccc1N(C)C(=O)c1ccc([Hg](O)c2nccs2)c([N+](=O)[O-])c1</smiles>

13

\begin{abstract}
Figure 4. CGRP receptor ligands:11)N-((R)-1-(((S)-6-ami-no-1-oxo-1-(4-pyridin-4-yl)piperazin1-yl)hexan-2-yl)amino)-3-(3,5-dibromo-4-hydroxyphenyl)1-oxopropan-2-yl)-4-(2-oxo-1,4-dihydroqui nazolin-3-(2H)-yl-piperidine-1-carboxamide 12) (R)-N-(1-([1,4'-bipiperidin]-1'-yl)-3-(7-methyl1H-indazol-5-yl)-1-oxopropan-2-yl)-4-(8-fluoro-2-oxo-1,4-dihydroquinazolin-3(2H)-yl) piperidine1-carboxamide 13) (S)-hydroxy (4-(methyl(o-tolyl)carbamoyl)-2-nitrophenyl) (thiazol-2-yl) sulfonium.
\end{abstract}

$\left.\left[{ }^{125} \mathrm{I}\right]-\mathrm{CGRP}\right)$ at the native human CGRP receptor in human neuroblastoma SK-N-MC cells and a $\mathrm{K}_{\mathrm{i}}$ of 0.047 $\mathrm{nM}$ at the recombinant human receptor [160]. Furthermore, the $\mathrm{K}_{\mathrm{i}}$ at the rhesus monkey receptor was $0.059 \mathrm{nM}$ [160] but lower values were found at the dog receptor (39 nM) and at the mouse receptor (19 nM) [160].

MK 8825 has been shown to exhibit a high selectivity for CGRP receptors among a multitude of other receptors as well as many enzymes and ion channels. The further modification of the substance resulted in the PET tracer $\left[{ }^{11} \mathrm{C}\right] \mathrm{MK} 4232$ (14) (Figure 5) which fulfilled the requirements for neuropeptide ligands not only by its high affinity to the receptor but also because of its moderate lipophilicity (LogD 3.38), good passive cell permeability of $25 \times 10^{-6} \mathrm{~cm} / \mathrm{s}$ and a low susceptibility for permeability-glycoprotein (P-gp) with a transport ratio of 1.7 which is lower than that of MK 8852 and MK 3207 [60]. Hostetler and colleagues [153] used MK 3207, MK 4232, telcagepant as well as the ${ }^{11} \mathrm{C}$-labelled CGRPA2 which is known to be a non-brain penetrant CGRP receptor antagonist $\left(\mathrm{K}_{\mathrm{i}} 0.018 \mathrm{nM}\right)$ in an innovative PET study. ${ }^{11} \mathrm{C}$-labelled MK4232 was applied in polyethylene glycol-solution with specific activities of $<37 \mathrm{GBq} / \mu \mathrm{mol}$ to humans and to rhesus monkeys. The authors 
<smiles>CN1C[C@](C)(c2cc(F)cc(F)c2)N(CC(=O)Nc2ccc3c(c2)C[C@@]2(C3)C(O)=Nc3ncccc32)C(=O)C12CCCC2</smiles><smiles>O=C(CN1C(=O)C2(CCCC2)NC[C@H]1c1cc(F)cc(F)c1)Nc1ccc2c(c1)C[C@@]1(C2)C(O)=Nc2ncccc21</smiles><smiles>O=C(NC1CCC(n2c(=O)[nH]c3ncccc32)CC1)N1CCC[C@@H](c2cccc(F)c2F)CN1C(F)(F)F</smiles><smiles>C[C@H](c1cc(F)cc(F)c1)N(CC(=O)Nc1ccc2c(c1)C[C@@]1(C2)C(O)=Nc2ncccc21)C(=O)C1(C)CCN([AlH2])CC1</smiles>

Figure 5. CGRP receptor ligands:14) 2-(R)-8-(3,5-difluoro phenyl)-6,8 dimethyl-10-oxo-6,9diazaspiro[4.5] de-can-9-yl)-N-(R)-2'-hydroxy-1,3-dihydrospiro[indene-2,3'-pyrrolo[2,3-b]pyridine]-5yl) acetamide] 15) 2-(R)-8-(3,5-difluoro- phenyl)-10-oxo-6,9-diazaspiro[4.5]decan-9-yl)$\mathrm{N}$-(R)-2'-hydroxy-1,3-dihydrospiro[indene-2,3'-pyrrolo [2,3-b] pyridine]-5yl) acetamide] 16) $\mathrm{N}$-((3R,6S)-6-(2,3-difluorophenyl)-2-oxo-1-(trifluoromethyl)azepan-3-yl)-4-(2-oxo-2,3-dihydro1H-imidazo-[4,5-b]pyridin-1-yl)piperidine-1-carboxamide 17) N-((S)-1-(3,5-difluoro-phenyl) ethyl)-N-(2-(((R)-2'-hydroxy-1,3-dihydrospiro[indene-2,3'-pyrrolo[2,3-b]pyridine]-5-yl) amino)2-oxoethyl)-1,4-dimethylpiperidine-4-carboxamide.

reported the following rank orders of magnitude for the three brain penetrant CGRP antagonists for receptor occupancy $\left(\right.$ Occ $\left._{50}\right)$ : MK4232 < MK3207 < telcagepant; for in vitro affinity $\left(\mathrm{K}_{\mathrm{i}}\right)$ : MK 4232 MK3207 << telcagepant and P-gp-efflux ratio: MK4232 << MK 3207 telcagepant. Hostetler et al. [153] showed that the receptor occupancy in cerebellum and brain stem commonly binding CGRP ligands achieved 43\% - 58\% if telcagepant was applied in doses tenfold larger than those used in clinical trials with efficient relief of migraine pain. Doses similar to those in a clinical phase III study resulted, however, only in a receptor occupancy between 4 and $10 \%$ suggesting that the action on central CGRP receptors was not the key component or not the only component in the action of telgacepant as an analgesic in migraine [153]. The question remained still unanswered, whether an enhancement of the occupancy of the central CGRP receptors can improve the efficacy of their antagonists. The 
contribution of vascular receptors to the imaging signal was low in the investigations of Hostetler et al. [153] as was demonstrated by imaging scans of the non-brain penetrant P-gp substrate CGRPA2. This suggests that CGRP receptors labelled with MK 4232 are localized predominantly in the gray matter.

\section{Bradykinin Receptors}

\subsection{Bradykinin and Its Receptors}

Bradykinin is a nonapeptide (RPPGFSPFR) with a half-life of 15 - $30 \mathrm{~s}$ [56] [161] [162] belonging to the vasoactive family of kinins together with kallidin and methionyl-lysyl-bradykinin which can be converted into bradykinin catalysed by aminopeptidases and furthermore by endogenous metalloproteases like angiotensinconverting enzyme (ACE) and neutral endopeptidase. The level of the autacoid in the blood is in the range between 0.2 and $7.1 \mathrm{pM}$ [56] [162] [163]. Bradykinin is obtained via cleavage of pro-kininogen by the protease kallikrein. Formation of kallikrein is initiated by the autoactivated (or plasmin activated) surface-bound factor XII in the blood vessels which converts the proenzyme prekallikrein into plasma kallikrein [56]. Bradykinin is part of inflammatory mechanisms contributing to hyper-responsiveness and allergic reactions like rhinitis, asthma as well as anaphylaxia [164]. Hereditary or acquired deficit of C1 esterase inhibitors, a compound of the complement system, can contribute to a bradykinin dependent angioedema. Similar effects can be supported by the use of angiotensin converting enzyme inhibitors in the treatment of hypertension, heart failure, diabetes and scleroderma [56]. The actions of bradykinin are manifold. In cardiovascular system it can induce release of prostacyclins, NO and endothelial derived hyperpolarizing factor (EDHF). In the respiratory tract it can cause bronchospasm and bronchoconstriction [55].

In the CNS bradykinin is suggested to be involved in excitation of primary sensory neurons, release of substance $\mathrm{P}$ and neurokinin A, development of acute algesic states as well as chronic inflammatory pain.

Bradykinin B1 receptors which are not expressed in a constitutive manner (with exception of the vascular system [116]) are upregulated under conditions of inflammation, infections or traumatic injuries [165].

The main target of bradykinin is the kinin B2 receptor which is expressed constitutively on mammalian cells including endothelial cells as well as neurons [161] [166], astrocytes, and microglia [167] [168]. Bradykinin B2 receptors have been identified at highest densities in the pleoglial periaqueductal gray, oculomotor and trochlear nuclei as well as in the circumventricular organs as Murone et al. reported 1997 from autoradiographic measurements in sheep brain and spinal cord [169]. Moderate densities have been found in diencephalon, hindbrain and spinal cord. Deleterious effects of bradykinin via the kinin B2 receptor are vasodilation and increase in vascular permeability [170] [171] especially under conditions of traumatic injury of the brain which can delay recovery from brain injury [161].

The degradation product of bradykinin, des-Arg'-bradykinin is acting via the B1 receptor [161]. B2 receptor, bradykinin and other components of the kallikrein-kinin system have been found in brain stem, cortex, cerebellum, hypothalamus and pituitary gland.

Both bradykinin receptor subtypes mediate their actions via $\mathrm{G}_{\mathrm{q} / 11}$ proteins [172].

\subsection{Bradykinin Receptor Ligands}

The hereditary angioedema (HAE) belongs to the rare diseases providing potential indication for the treatment with drugs interfering with actions of bradykinin and its binding sites. Nevertheless, it attracts much of the attention dedicated to bradykinin actions in vivo. Several therapeutic proposals focus on different steps of the kinin-kallikrein-bradykinin cascade. Compounds developed for treatment of HAE include C1 esterase inhibitors, inhibitors of the conversion of kininogen to bradykinin via inhibition of plasma kallikrein, antagonists of bradykinin B2 receptors and inhibitors of plasminogen activation [173]. Icatibant is one of the B2 antagonists successfully tested with a subcutaneous route of application [174].

Most bradykinin receptor ligands tested experimentally and clinically are peptide compounds and agonists at their receptor. E.g. the peptide ligand HPP-HOE140 showed $\mathrm{K}_{\mathrm{i}}$ values of 0.32, 1.37 and $157 \mathrm{nM}$ in displacement studies with bradykinin, HOE-140 and D-arg[Hyp ${ }^{3}$ and D-Phe ${ }^{7}$, Leu $\left.{ }^{8}\right]$ bradykinin, respectively, in sheep brain autoradiography [169]. However, also some non-peptide ligands have been presented e.g. by Aramori et al. (FR167344, S1567 (18, Figure 6) and FR173657 (19, Figure 6) [164] [175] as well as by Pruneau et al. 1999 [176] (the B2 antagonist LF 16-0687/Anatibant) (20, Figure 6). 


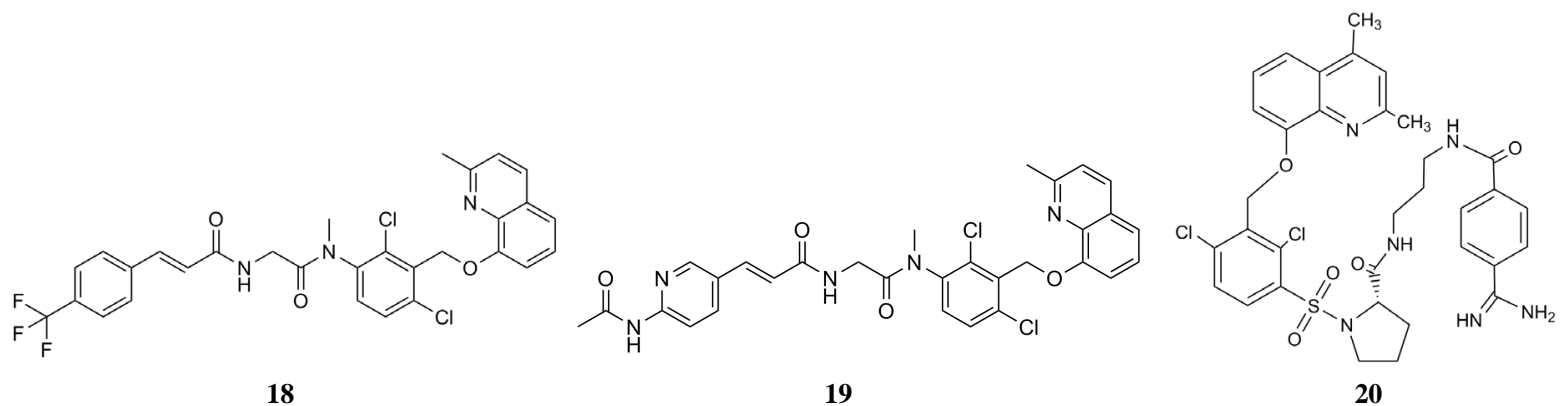

Figure 6. Bradykinin receptor ligands:18) (E)-N-(2-((2,4-dichloro-3-(((2-methylquinolin-8-yl)oxy)methyl) phe-nyl)methyl) amino)-2-oxoethyl)-3-((4-trifluoromethyl)phenyl) acrylamide 19) (E)-3(6-acetamido-3-pyridyl)-N-[N-2-4-dichloro-3-[(2methyl-8-quinolinyl)oxymethyl] phe-nyl-N-methylamino carbonyl-methyl]acrylamide) 20)(S)-N-(3-(4-carbamimidoylbenzamido)propyl)-1-((2,4-dichloro-3-(((2,4-dimethylquinolin-8-yl)oxy)methyl)phenyl)sulfonyl)pyrrolidine-2-carboxamide.

FR 173657 is an antagonist at the B2 receptor and has been shown to suppress responses to bradykinin in vivo [175]-[177]. LF 16-0687 constitutes another lead structure and has been demonstrated to bind with high affinity to the B2 receptor in different species and tissues. For instance human, rat and guinea pig recombinant B2 receptors revealed $\mathrm{K}_{\mathrm{i}}$ values of $0.67,1.74$ and $1.37 \mathrm{nM}$.

\section{Neurokinin Receptors}

\subsection{Mammalian Neurokinins and Their Receptors}

The family of tachykinins includes in humans ten compounds of which eight share the carboxy terminal sequence F-X-G-L-M (X stands either for an aromatic amino acid or a ß-aliphatic amino acid) [178]-[180]: substance P (SP), neurokinin A (NK-A also called substance K), neurokinin B (NK-B also called neuromedin K) [181], neuropeptide K (NP-K), neuropeptide $\gamma$ (NPG) [181]-[183] and human hemokinin-1 [184] belonging like EKA, B, C and EKD to the group of endokinins [179] [185]. The number of a. a.rs of these tachykinins has been found to be between 10 - 36. Substance P (RPKPQQFFGLM) contains 11 a.a.r [181] [186]. The amino acid sequences of the further petides are for NKA:HKTDSFVGLM; NKB:DMHDFFVGLM and NKG, which is the most abundant in the body: DAGHGQISHKRHKTDSFVGLM, NP K: DADSSIEKQVALLKALYGHGQISHKRHKTDSFVGLM; EKA/B: GKASQFFGLM [185]; EKC, EKD: KKAYQLEHTFQGLL, and VGAYQLEHTFQGLL [187] and hHK1: TGKASQFFGLM [188]. The first five of these tachykinins occur by cleaving of 4 precursor pro-peptides. These precursor pro-tachykinins, $\alpha, \beta, \gamma$ and $\delta$ are encoded by two genes. PPT-B gene (alternatively PPT-II or TAC3) encodes the NK-B and PPT-A gene (alternatively PPT-I or TAC1) the other four mammalian tachykinins [185] [189]. Hemokinins as well as endokinins (A-D) are encoded by the TAC4 gene (alternatively PPT-C gene). Proteolytic processing of a 128 a.a.r. precursor pro-tachykinins C results in the formation of hemokinin which has been shown to interact with the neurokinin 1 receptor with a 200- to 250 -fold higher selectivity than substance P [184] [189]. Hemokinin 1 is presumed to be more resistant to proteolysis than Substance P [184]. Endokinins and hemokinins are not regarded to be conserved throughout mammalian species in contrast to the other tachikinins mentioned above [54] [185].

Tachikinins are identified in neuronal but also in non-neuronal cells like endothelium and inflammatory cells [190]-[192]. However, NKB has been detected only in the brain and in the placenta [179] [193] [194].

Three types of tachikinin receptors have been identified up to now: TACR1 (NK1), TACR2 (NK2) and TaCR3 (NK3) [8] which may influence a myriad of cell biological effects including diverse actions on cell proliferation, smooth muscle contraction, vasodilation, plasma extravasation, neurogenic inflammation and hematopoiesis [185] [195]. Neurokinin receptors influence via $\mathrm{G}_{\mathrm{q} / 11}$-protein phospholipase $\mathrm{C}$ and $\mathrm{Ca}^{2+}$ levels [17]. However, also the ß-arrestin-mediated actions on apoptosis are objective of recent investigations [196].

NK1 receptors have been identified in the brains of gerbils and humans with a content up to 607 and 432 fmoles/mg, respectively [44], whereas NK2 and NK3 receptors achieve only 7.3 (rat) [117] and 31.2 fmoles/mg [59] [118], respectively. For the NK1 receptor the sequence of affinities of the preferred neurokinins is SP = HK-1 $>$ NPG $>$ NKA $=$ NPK $>$ NKB [184] [197]. For the NK2 receptor the binding of tachikinins has been described in the following rank order: NPK $=$ NPG $>$ NKA $>$ NKB $>$ SP [17] [192]. At the NK3 receptor the rank 
order of potency has been described with NKB > NKA > SP. A distinct haemokinin-1 receptor has been proposed but not characterized up to now [8].

Several $\beta$-arrestins may trigger via involvement in multi protein complexes signal transduction mechanisms like mitogen-activated protein kinase (MAPK) and extracellular signal-regulated kinases 1 and 2 (ERK 1/2)dependent pathways with influence on proliferative processes. Inflammatory and immunological actions are regarded with rising attention as potential routes to new approaches in cancer therapy (including also cancer- and metastatically induced pain) focussing on the influence of the microenvironment of tumour or precancer cells [8].

A role of neurokinin receptors of the brain contributing to analgesia has been suggested in the late 90ties [198], but such a direct involvement in brain-linked mechanisms could repeatedly not be confirmed. Species differences in neurokinin receptor expression impede additionally conclusions about involvement in such processes [44] [199]. An indirect involvement would be possible also via antidepressive and anxiolytic mechanisms, which have been intensively investigated leading to distinct results [200].

However, there is no doubt that NK1 receptors have been found in different parts of the spinal cord especially in the dorsal horn [201] which is the first relay station for nociceptive input to the main central pathway for pain, the lateral spinothalamic tract [202]. Autoradiographic investigations revealed expression of NK1, NK2 and NK3 receptors in cervical, thoracic, lumbar and sacral spinal cord sections in the range between 1.6 to 13.2 $\mathrm{fmol} / \mathrm{mg}$ tissue wet weight [203] (Table 1). Processes localized in the spinal cord are brought more and more in the focus of tomographic imaging also using positron emitting tracer compounds or single photon emitters in humans, however, more usually with metabolic tracers [204] [205]. For instance $\left[{ }^{11} \mathrm{C}\right] \mathrm{N}$-methyl-4,4'-diaminostilbene (MeDAS) has been employed for the visualization of alterations in demyelinization diseases in models of lysophosphatidyl (LPC) induced focal demyelinization, experimental autoimmune encephalomyelitis (EAE) or multiple sclerosis [206] [207].

The contribution of NK1 receptors to migraine attacks is predominantly due to leakage of plasma protein from postcapillary venules and adhesion of leukocytes to venular endothelium [57]. NK1 receptor antagonists, however, have not been able to suppress such relatively unspecific alterations in the homeostasis of brain tissue and interactions with inflammatory cells.

The use of NK receptor antagonists in clinical routine applications is restricted currently to NK1 antagonists; e.g. aprepitant has been shown to be effective in the treatment of drug-induced vomiting. NK3 receptor stimulation can antagonize the excitation of dopaminergic neurons in the ventral tegmental area. The NK3 receptor in the brain typically is found in cortical regions, nuclei of amygdala, hippocampus as well as midbrain structures e.g. substantia nigra, ventral tegmental area and raphe nuclei [208]-[210]. However, it is present in the cerebral regions in low density in comparison with NK1 and NK2 receptors [211].

\subsection{Non-Peptide Neurokinin Receptor Ligands}

A number of non-peptide antagonists at different NK receptor subtypes has been described and achieved in clinical test also phase III [211]. The spectrum of diseases for which such compounds were created was broad and included mental and mood diseases, alcohol craving, overacting bladder, vomiting and also pain syndroms [211]. The NK1 receptor has been found to be widely distributed in the brain particularly within the striatum and with negligible density in the cerebellum [212] and relatively early compounds were developed, which could displace $\left[{ }^{3} \mathrm{H}\right]$ substance $\mathrm{P}$ in caudate membranes. One first highly specific of these substances was CP 96345 (22, Figure 7 and Table 2). More precisely it was the (2S,3S)-enatiomer which showed the high affinity of $4 \mathrm{nM} \mathrm{[152]} \mathrm{[213].}$ However, the compound had a 100fold higher affinity to the NK1 receptor in rat and mouse than in humans and other species. CP96345 was free of any agonistic action at the NK1 receptor but at higher doses not free of nonspecific binding to $\mathrm{Ca}^{2+}$ channels. This disadvantage could be reduced in the compound CP 99.994, which showed a 100fold lower affinity to the L-type $\mathrm{Ca}^{2+}$ channel in comparison to CP96.345. Although CP 99994 was tested with some success in preclinical models of nociception and inflammation it could not reveal an advantage compared to ibuprofen in postoperative treatment after dental surgery in humans [214]. GR 205171 (23, Figure 8) ( $\mathrm{K}_{\mathrm{i}} 0.4 \mathrm{nM}$; [215], a trifluoromethyl substituted enantiomer of GR203040 (24, Figure 8) was a further compound with even more reduced nonspecific binding in calcium channels and was in clinical investigations effective to reduce postoperative nausea. Recently, Zamuner et al. [216] used ${ }^{11} \mathrm{C}$-labelled GR 205171 to test the occupancy of the NK1 receptor by the NK1 antagonist casopitant. Aprepitant (25, Figure 8) (L754030; $\mathrm{K}_{\mathrm{i}}=0.1$ 
<smiles></smiles>

21<smiles>COc1ccccc1CN[C@H]1C2CCN(C2)[C@H]1C(c1ccccc1)c1ccccc1</smiles>

22

Figure 7. Neurokinin 1 receptor ligands:21) 5-(2-((2S,3S)-2-((3,5-bis(trifluoromethyl)benzyl) oxy)-3-phenylmorpholino) ethyl)-2,4-dihydro-3H-1,2,4-triazol-3-one 22)(2S,3S)-2-benz-hydryl$\mathrm{N}$-(2-methoxybenzyl)quinuclidin-3-amine.

$\mathrm{nM}$ ) was the first exogenous ligand supporting indications that NK1 might play a role in depression and anxiety disorders by preclinical observations [217] [218]. However, in clinical therapeutics its application is restricted to supportive therapy in patients subjected to chemotherapeutic treatment of cancer or in prevention of postoperative nausea and vomiting (PONV). The compound has been launched for application in chemotherapy induced nausea and vomiting (CINV) in 2003 and two years later for PONV [211]. Tattersall et al. reported in 2000 a $\mathrm{K}_{\mathrm{d}}$ of $86 \mathrm{pM}$ (hNK1) for the selective and brain penetrant NK1 receptor antagonist and for its phosphorylated prodrug, L-758,298, a $\mathrm{K}_{\mathrm{d}}$ of $4 \mathrm{nM}$ (hNK1) [219]. [ $\left.{ }^{11} \mathrm{C}\right] \mathrm{GR} 205171$ (23, Figure 8) [44] [216] as the first PET ligand was followed by $\left[{ }^{18} \mathrm{~F}\right] \mathrm{SPA}-\mathrm{RQ}$ (26, Figure 8) with similar activity. $\left[{ }^{18} \mathrm{~F}\right] \mathrm{SPA}-\mathrm{RQ}$ shows with a $\mathrm{K}_{\mathrm{d}}$ of $67 \mathrm{pM}$ an affinity to the NK1-receptor comparable with that of aprepitant and additionally a log P of 1.8 confirming a moderate brain penetrance [220]-[222]. It shows the highest binding in striatum, followed by amygdala, and parietal and occipital cortex [223]. Phase I clinical study on panic and anxiety disorders have been started in 2004 (NCT00088738).

A lower affinity has been found for the selective NK1 receptor ligand $\left[{ }^{11} \mathrm{C}\right] \mathrm{R} 116301$ (27, Figure 8) [227] [228] which has been subjected to a first in vivo evaluation byWolfensberger et al. [212] in humans. Following rank order of magnitude for the affinities of important NK1receptor ligands has been reported: SPA-RQ > GR205171 > aprepitant > R116301 > substance P [44] [212]. Further PET tracers which were earlier evaluated appeared less suitable for clinical applications [229]. Ovepitant, L-759274, CP 122721 and casopitant are further antagonists tested clinically. NK1 and NK2 receptors are found in peripheral tissue, especially the gastrointestinal tract. NK2 is additionally found typically in smooth muscles of small and large bronchi and brochioli of human airways. In lung tissues containing membranous airways a fourfold increase in NK2 expression has been described [211] [230]. The NK2 subtype in the brain has been shown by mRNA measurements in caudate putamen, hippocampus, substantia nigra [231]. Also with the intention of therapeutic use in targets of the peripheral nervous system a number of NK2 receptor antagonists has been developed and included in clinical tests e.g. saredutant (SR 48968; [233]), and nepadutant [234].

However, a protective effect of NK2 receptor antagonists on allergene induced response in asthmatics could neither be confirmed [235] for the specific NK2 receptor antagonists nor for NK1/NK2 antagonists. Saredutant was used successfully in preclinical behavioral models of anxiety and suppression and was similar effective as diazepam and buspirone in models of social behavior were it enhanced markedly the time of interaction [236].

SR142801 (osanetant) [237], SB223412 (talnetant) [238] and TAK 637 [239] (Table 2) have been shown to bind selectively to the NK3 receptor. While the NK2 receptor ligand shows a favorable log P for passage of bbb or bscb, the few available non-peptide NK3 receptor ligands are too lipophilic for the use as a PET tracer [200]. The indications for the use of NK3 receptors ligands remain restricted to CNS and spinal cord because of the specific presence of this receptor in these regions. A number of clinical studies dedicated to a therapeutic use 
<smiles>COc1ccc(-n2nnnc2C(F)(F)F)cc1CN[C@H]1CCCN[C@H]1c1ccccc1</smiles><smiles>COc1ccc(-n2cnnn2)cc1NC1CCCNC1c1ccccc1</smiles><smiles>C[C@@H](O[C@H]1COCCN1CCc1n[nH]c(=O)[nH]1)c1ccc(F)cc1</smiles><smiles>Cc1cccc(C)c1NC(=O)CN1CCN2CCC(C[C@@H](Cc3ccccc3)N2C(=O)c2cc(C(F)(F)F)cc(C(F)(F)F)c2)C1</smiles>

\begin{abstract}
Figure 8. Neurokinin 1 receptor ligands:23) (2S,3S)-N-(2-methoxy)-5-(5-trifluor-methyl)1H-tetra-zol-1-yl)benzyl)-2-phenylpiperidin-3-amine 24) (2S,3S)-N-(2-methoxy-5-(1Htetrazol-1-yl)benzyl)-2-phenylpiperidin-3-amine 25) 5-(2-((2R,3S)-2-((R)-1-(3,5-bis(trifluoromethyl)phenyl) ethoxy)-3-(4-fluorophenyl)-morpholino)ethyl)-2,4-dihydro-3H-1, 2,4-triazol-3-one 26) (2S,3S)-N-(2-(fluoromethoxy)-5-(5-trifluor-methyl)-1H-tetrazol-1yl)benzyl)-2-phenyl-piperidin-3-amine 27) 2-(4-((2R,4S)-2-benzyl-1-(3,5-bis (trifluoromethyl)benzoyl)piperidin-4-yl) piperazin-1-yl-N-(2,6-dimethyl phenyl) acetamide.
\end{abstract}

of NK3 receptor antagonists in schizophrenia, depression and panic disease were discontinued [211].

\title{
7. Conclusions
}

The five receptor types enclosed in this study are still in the focus of many questions related to their potential in therapeutics of pathogenic alterations of pain circuits including structures in brain and spinal cord but also in PNS and enteric nervous system [211]. Especially for neurokinin receptors, a mismatch between preclinical and clinical results not only related directly to nociception but also to mood disorders and other mental diseases [44] makes it difficult to evaluate the potential clinical efficiency of novel drugs suitable for the development of PET and SPECT imaging probes.

Regarding development of pharmacophore models, also basic structures of NT3 (sortilin) and CGRP receptors with transmembrane domains distinct from the common GPCRs or with multimeric complex composition (see RAMP and CLR as receptor associated proteins) are a new challenge to the right choice of suitable lead 
compounds [54] [130].

Hitherto, opioid receptor ligands remain the best established neuropeptide receptor ligands for PET on the analgesic route. These, like $\left[{ }^{11} \mathrm{C}\right]$ carfentanil and $\left[{ }^{18} \mathrm{~F}\right]$ cyclofoxy have been used extensively for modelling of pharmacodynamics and pharmacokinetics also in mokeys and humans [90] [91] [95] [96]. On the analgesic route of pain circuits, however, not only $\mu$ opioid receptors but also $\kappa$-receptors appear to be of great relevance not only in relays of the spinothalamic tract conveying signals to higher centers but also as potential modulators of dopamine release in cortical and subcortical brain areas [240]. Most auspicious approach for $\kappa$ receptor ligands was described in 2003 by Thomas et al. [104] with the $\kappa$ antagonist $\left[{ }^{11} \mathrm{C}\right]$ MEJDTic(5). The labelling procedure of the substance was improved in 2008 by Poisnel et al. [98] and labelling of MeJDTic analogues with fluorine-18 has been announced. However, in contrast to $\left[{ }^{11} \mathrm{C}\right]$ MeJDTic, for the more recently developed KOR antagonist $\left[{ }^{11} \mathrm{C}\right] \mathrm{LY} 2795050$ (8) and the more established agonist and PET tracer $\left[{ }^{11} \mathrm{C}\right] \mathrm{GR} 103545(3)$ have been reported in vivo imaging results in primates already [103] [107] [241]. These demonstrated for [ $\left.{ }^{11} \mathrm{C}\right] \mathrm{GR} 103545$ a markedly higher brain accumulation than for its enantiomer $\left[{ }^{11} \mathrm{C}\right] \mathrm{GR} 89696$ and for $\left[{ }^{11} \mathrm{C}\right] \mathrm{LY} 2795050$ the most convincing standard uptake values [107] [241]. Simultaneously, entrapment in cellular compartments or activation of c-jun terminal kinase 1 (inductor of autophagosome formation) discussed to prolong the action of JDTic is not known for the shorter acting LY2795050 [242]. For $\left[{ }^{11} \mathrm{C}\right]$ MeJDTic the relatively low accumulation in the brain is attributed to enrichment of the tracer in liver, kidney and lung tissue [98]. Efforts to improve high throughput screening and hit refinement strategies give rise for expectations of further candidate structures for potential $\kappa$ subtype specific PET tracers [240]. The most interesting non-peptide receptor ligand with a role in vascular and inflammatory processes involved in pain circuits appears to be the CGRP antagonist MK4232 (14) evaluated by the group of Bell and Hostetler [60] [153]. The CGRP antagonist telcagepant had to be recalled recently because of adverse effects in the liver. Thus the novel PET tracer provides the basis for the start into neuroimaging diagnostics of CGRP receptor alterations whereas bradykinin receptor ligands and also neurotensin receptor ligands presented in the literature showed physico-chemical limitations which prevent or hamper an employment as tracer for neuroimaging.

\section{Acknowledgements}

I would like to gratefully acknowledge the assistance provided by Rike Preiss at completion of the manuscript and the helpful advice by Pr. Peter Illes in some pharmacological issues. This paper is dedicated to Pr. ErnstGeorg Krause (Max-Delbrück-Centre, Berlin-Buch) on the occasion of his $80^{\text {th }}$ birthday.

\section{References}

[1] MaassenVanDenBrink, A. and Chan, K.Y. (2008) Neurovascular Pharmacology of Migraine. European Journal of Pharmacoloy, 585, 313-319. http://dx.doi.org/10.1016/j.ejphar.2008.02.091

[2] Vecchia, D. and Pietrobon, D. (2012) Migraine: A Disorder of Brain Excitatory-Inhibitory Balance? Trends in Neurosciences, 35, 507-520. http://dx.doi.org/10.1016/j.tins.2012.04.007

[3] Charcot, J.M. (1877) Lectures on Diseases of the Nervous System. The New Sydenham Society, London, 137.

[4] Charcot, J.M. (1892) De la Maladie de Morvan. Sciatique ancienne avec atrophie musculaire et troubles de la sensibilité. In: Babé, V.V. and Guinon, G., Eds., Clinique des maladies du systéme nerveux, Tome I, Progres Medical, Paris, 155.

[5] Handy, C.R., Krudy, C., Boulis, N. and Federici, T. (2011) Pain in Amyotrophic Lateral Sclerosis: A Neglect Aspect of Disease. Neurology Research International, 2011, Article ID: 403808. http://dx.doi.org/10.1155/2011/403808

[6] Winkler, E.A., Sengillo, J.D., Sullivan, J.S., Henkel, J.S., Appel, S.H. and Zlokovic, B.V. (2013) Blood-Spinal Cord Barrier Breakdown and Pericyte Reductions in Amyotrophic Lateral Sclerosis. Acta Neuropathologica, 125, 111-120. http://dx.doi.org/10.1007/s00401-012-1039-8

[7] Hunzinga, M.M. and Peltier, A. (2007) Painful Diabetic Neuropathy: A Management Centered Review. Clinical Diabetes, 25, 6-15. http://dx.doi.org/10.2337/diaclin.25.1.6

[8] Rosso, M., Munoz, M. and Berger, M. (2012) The Role of Neurokinin-Receptor in the Microenvironment of Inflammation and Cancer. Scientific World Journal, 2012, Article ID: 381434.

[9] Edvinsson, L., Villalon, C.M. and MaasssenVanDenBrink, A. (2012) Basic Mechanisms of Migraine and Its Acute Treatment. Pharmacology \& Therapeutics, 136, 319-333. http://dx.doi.org/10.1016/j.pharmthera.2012.08.011

[10] Dobner, P.R. (2006) Neurotensin and Pain Modulation. Peptides, 27, 2405-2414. 
http://dx.doi.org/10.1016/j.peptides.2006.04.025

[11] Fichna, J., Janecka, A., Costentin, J. and Do Rego, J.C. (2007) The Endomorphin System and Its Evolving Neurophysiological Role. Pharmacological Reviews, 59, 88-123. http://dx.doi.org/10.1124/pr.59.1.3

[12] Maarrawi, J., Peyron, R., Mertens, P., Costes, N., Magnin, M., Sindou, M., Laurent, B. and Garcia-Larrea, L. (2007) Differential Brain Opioid Receptor Availability in Central and Peripheral Neuropathic Pain. Pain, 127, 183-194. http://dx.doi.org/10.1016/j.pain.2006.10.013

[13] Leavitt, S.B. (2009) Opioid Antagonists, Naloxone \& Naltrexone-Aids for Pain Management. Pain Treatment Topics, pai-topics.org, Glenview, 1-16.

[14] LaFrance, M., Roussy, G., Belleville, K., Maeno, H., Beaude, N., Wada, K. and Sarret, P. (2010) Involvement of NTS2 Receptors in Stress-Induced Analgesia. Neuroscience, 166, 639-652. http://dx.doi.org/10.1016/j.neuroscience.2009.12.042

[15] Shulman, J.M. and Strichartz, G.R. (2008) Local Anesthetic Pharmacology. In: Golan, D.E., Tashjian Jr., A.H., Armstrong, E.J. and Armstrong, A.W., Eds., Principles of Pharmacology, 2nd Edition, Wolters Kluwer, Lippincott Williams \& Wiilkins, Philadelphia, 145-160.

[16] Henriksen, G. and Willoch, F. (2008) Imaging of Opioid Receptors in the Central Nervous System. Brain, 131, 1171-1196. http://dx.doi.org/10.1093/brain/awm255

[17] Malherbe, P., Bissantz, C., Marcuz, A., Kratzeisen, C., Zenner, M.T., Wettstein, J.G., Ratni, H., Riemer, C. and Spooren, W. (2008) Me-Talnetant and Osanetant Interact with Overlapping but Not Identical Binding Pockets in the Human tachykinin Neurokinin 3 Receptor Transmembrane Domains. Molecular Pharmacology, 73, 1736-1750. http://dx.doi.org/10.1124/mol.107.042754

[18] Aziz, F. (2012) Neurokinin-1 Receptor Antagonists for Chemotherapy-Induced Nausea and Vomiting. Annals of Palliative Medicine, 1, 130-136.

[19] Gurevich, E.V., Tesmer, J.J., Mushegian, A. and Gurevich, V.V. (2012) G-Protein Coupled Receptor Kinases: More than Just Kinases and Not Only for GPCRS. Pharmacology \& Therapeutics, 133, 40-69. http://dx.doi.org/10.1016/j.pharmthera.2011.08.001

[20] Rajagopal, S., Rajagopal, K. and Lefkowitz, R.J. (2010) Teaching Old Receptors New Tricks: Biasing Seven-Transmembrane Receptors. Nature Reviews Drug Discovery, 9, 373-386. http://dx.doi.org/10.1038/nrd3024

[21] Milan-Lobo, L. and Whistler, J.L. (2011) Heteromerization of the $\mu$-and $\boldsymbol{\delta}$-Opioid Receptors Produces Ligand-Biased Antagonism and Alters $\mu$-Receptor Trafficking. Journal of Pharmacology and Experimental Therapeutics, 337, 868875. http://dx.doi.org/10.1124/jpet.111.179093

[22] Lefkowitz, R.J. (2013) A Brief History of G-Protein Coupled Receptors (Nobel Lecture). Angewandte Chemie International Edition, 52, 6367-6378. http://dx.doi.org/10.1002/anie.201301924

[23] Shukla, A.K., Manglik, A., Kruse, A.C., Xiao, K., Reis, R., Tseng, W.C., Staus, D.P., Hilger, D., Uysal, S., Huang, L.Y., Paduch, M., Tripathi-Shukla, P., Koide, A., Koide, S., Weis, W.I., Kossiakoff, A.A., Kobilka, B.K. and Lefkowitz, R.J. (2013) Structure of Active $\beta$-Arrestin-1 Bound to a G-Protein-Coupled Receptor Phosphopeptide. Nature, 497, 137-142. http://dx.doi.org/10.1038/nature12120

[24] Bohn, L.M., Dykstra, L.A., Lefkowitz, R.J., Caron, M.G. and Barak, L.S. (2004) Relative Opioid Efficacy Is Determined by the Complements of the G Protein-Coupled Receptor Desensitization Machinery. Molecular Pharmacology, 66, 106-112. http://dx.doi.org/10.1124/mol.66.1.106

[25] Raehal, K.M., Walker, J.K. and Bohn, L.M. (2005) Morphine Side Effects in $\beta$-Arrestin 2 Knockout Mice. Journal of Pharmacology and Experimental Therapeutics, 314, 1195-1201. http://dx.doi.org/10.1124/jpet.105.087254

[26] Groer, C.E., Tidgewell, K., Moyer, R.A., Harding, W.W., Rothman, R.B., Prisinzano, T.E. and Bohn, L.M. (2007) An Opioid Agonist That Does Not Induce $\mu$-Opioid Receptor-Arrestin Interactions or Receptor Internalization. Molecular Pharmacology, 71, 549-557. http://dx.doi.org/10.1124/mol.106.028258

[27] Venkatakrishnan, A.J., Deupi, X., Lebon, G., Tate, C., Schertler, G.F. and Babu, M.M. (2013) Molecular Signatures of G-Protein-Coupled Receptors. Nature, 494, 185-194. http://dx.doi.org/10.1038/nature11896

[28] Albizu, L., Moreno, J.L., Gonzalez-Maeso, J. and Sealfon, S.C. (2010) Heteromerization of G-Protein-Coupled Receptors: Relevance to Neurological Disorders and Neurotherapeutics. CNS \& Neurological Disorders-Drug Targets, 9, 636-650. http://dx.doi.org/10.2174/187152710793361586

[29] Fuxe, K., Marcellino, D., Borroto-Escuela, D.O., Frankowska, M., Ferraro, L., Guidolin, D., Ciruela, F. and Agnati, L.F. (2010) The Changing World of G Protein-Coupled Receptors: From Monomers to Dimers and Receptor Mosaics with Allosteric Receptor-Receptor Interactions. Journal of Receptors and Signal Transduction, 30, 272-283. http://dx.doi.org/10.3109/10799893.2010.506191

[30] Rasmussen, S.G.F., Choi, H.J., Rosenbaum, D.M., Kobilka, T.S., Thian, F.S., Edwards, P.C., Burghammer, M., Ratna- 
la, V.R.P., Sanishvili, R., Fischetti, R.F., Schertler, G.F., Weis, W. and Kobilka, B.K. (2007) Crystal Structure of the Human $\beta 2$ Adrenergic G-Protein Coupled Receptor. Nature, 450, 383-387. http://dx.doi.org/10.1038/nature06325

[31] Jordan, B.A. and Devi, L.A. (1999) G-Protein-Coupled Receptor Heteromerization Modulates Receptor Function. Nature, 399, 697-700. http://dx.doi.org/10.1038/21441

[32] George, S.R., Fan, T., Xie, Z., Tse, R., Tam, V., Varghese, G. and O’Dowd, B.F. (2000) Oligomerization of $\mu$ and $\delta$ Opioid Receptors: Generation of Novel Functional Properties. Journal of Biological Chemistry, 275, 26128-26135. http://dx.doi.org/10.1074/jbc.M000345200

[33] Borroto-Escuela, D.O., Romero-Fernandez, W., Rivera, A., van Craenenbroeck, K., Tarakanov, A.O., Agnati, L.F. and Fuxe, K. (2013) On the G-protein-Coupled Receptor Heteromers and Their Allosteric Receptor-Receptor Interactions in the Central Nervous System: Focus on Their Role in Pain Modulation. Evidence-Based Complementary and Alternative Medicine, 2013, Article ID: 563716. http://dx.doi.org/10.1155/2013/563716

[34] Chakrabarti, S., Liu, N. J.and Gintzler, A.R. (2010) Formation of $\mu / \kappa$ Opioid Receptor Heterodimer Is Sex Dependent and Mediates Female-Specific Opioid Analgesia. Proceedings of the National Academy of Sciences of the United States of America, 107, 20115-20119. http://dx.doi.org/10.1073/pnas.1009923107

[35] Vilardaga, J.P., Nikolaev, O.V., Lorentz, K., Ferrandon, S., Zhuang, Z. and Lohse, M.J. (2008) Direct Inhibition of G-Protein Signaling by Cross Conformational Switches between $\alpha 2 a$ Adrenergic and $\mu$ Opioid Receptors. Nature Chemical Biology, 4, 126-131. http://dx.doi.org/10.1038/nchembio.64

[36] Vilardaga, J.P., Agnati, L.F., Fuxe, K. and Ciruela, F. (2010) G-Protein-Coupled Receptor Heteromer Dynamics. Journal of Cell Science, 123, 4215-4220. http://dx.doi.org/10.1242/jcs.063354

[37] Smith, N.J. and Milligan, G. (2010) Allostery at G-Protein-Coupled Receptor Homo-and Heteromers: Uncharted Pharmacological Landscapes. Pharmacological Reviews, 62, 701-725.http://dx.doi.org/10.1124/pr.110.002667

[38] Dickenson, A.H. (1995) Spinal Cord Pharmacology of Pain. British Journal of Anaesthesia, 75, 193-200. http://dx.doi.org/10.1093/bja/75.2.193

[39] Craik, D.J., Fairlie, D.P., Liras, S. and Price, D. (2013) The Future of Peptide-Based Drugs. Chemical Biology Drug Design, 81, 136-147. http://dx.doi.org/10.1111/cbdd.12055

[40] Bartanusz, V., Jezova, D., Alajajian, B. and Digicaylioglu, M. (2011) The Blood-Spinal Cord Barrier: Morphology and Clinical Implications. Annals of Neurology, 70, 194-206. http://dx.doi.org/10.1002/ana.22421

[41] Xanthos, D.N., Püngel, I., Wunderbaldinger, G. and Sandkühler, J. (2012) Effects of Peripheral Inflammation of the Blood-Spinal Cord Barrier. Molecular Pain, 8, 44. http://dx.doi.org/10.1186/1744-8069-8-44

[42] Naliboff, B.D., Munokata, J., Fullerton, S., Gracely, R.H., Kodner, A., Harraf, F. and Mayer, E.A. (1997) Evidence for Two Distinct Perceptual Alterations in Irritable Bowl Syndrome. Gut, 41, 505-512. http://dx.doi.org/10.1136/gut.41.4.505

[43] Okano, S., IKeura, Y. and Inatomi, N. (2002) Effects of Tachikinin NK1 Receptor Antagonists on the Viscerosensory Response Caused by Colorectal Distention in Rabbits. Journal of Pharmacology and Experimental Therapeutics, 300, 925-931. http://dx.doi.org/10.1124/jpet.300.3.925

[44] Griffante, C., Carletti, R., Andreetta, F. and Corsi, M. (2006) [3H] GR205171 Displays Similar NK1 Receptor Binding Profile in Gerbils and Human Brain. British Journal of Pharmacology, 148, 39-45. http://dx.doi.org/10.1038/sj.bjp.0706697

[45] Gaddum, J.H. and Schild, H. (1935) Depressor Substances in Extracts of Intestine. Journal of Physiology (London), 83, $1-14$.

[46] von Euler, U.S.V. and Gaddum, J.H. (1931) An Unidentified Depressor Substance of the Dog. The Journal of Physiology, 72, 74-87.

[47] von Euler, U.S.V. and Pernow, B. (1954) Effects of Intraventricular Administration of Substance P. Nature, $174,184$. http://dx.doi.org/10.1038/174184a0

[48] Willoch, F., Schindler, F., Wester, H.J., Empl, M., Straube, A., Schwaiger, M., Conrad, B. and Tölle, T.R. (2004) Central Poststroke Pain and Reduced Opioid Receptor Binding within Pain Processing Circuitries: A $\left[{ }^{11} \mathrm{C}\right]$ Diprenorphine PET Study. Pain, 108, 213-220. http://dx.doi.org/10.1016/j.pain.2003.08.014

[49] Sprenger, T., Valet, M., Boecker, H., Henriksen, G., Spilker, M.E., Willoch, F., Wagner, K.J., Wester, H.J. and Tölle, T.R. (2006) Opioidergic Activation in the Medial Pain System after Heat Pain. Pain, 122, 63-67. http://dx.doi.org/10.1016/j.pain.2006.01.003

[50] Maarrawi, J., Peyron, R., Mertens, P., Costes, N., Magnin, M., Sindou, M., Laurent, B. and Garcia-Larrea, L. (2007) Differential Brain Opioid Receptor Availability in Central and Peripheral Neuropathicpain. Pain, 127, 183-194. http://dx.doi.org/10.1016/j.pain.2006.10.013 
[51] Henriksen, G. and Willoch, F. (2008) Imaging of Opioid Receptors in the Central Nervous System. Brain, 131, 11711196. http://dx.doi.org/10.1093/brain/awm255

[52] Sprouse-Blum, A.S., Smith, G., Sujai, D. and Don Parsa, F. (2010) Understanding Endorphins and Their Importance in Pain Management. Hawai Medical Journal, 69, 70-71.

[53] Brooks, D.J. (2010) Imaging Approaches to Parkinson Disease. Journal of Nuclear Medicine, 51, 596-609. http://dx.doi.org/10.2967/jnumed.108.059998

[54] Kleczkowska, P. and Lipkowski, A.W. (2013) Neurotensin and Neurotensin Receptors: Characteristic Structure-Activity Relationship and Pain Modulation-A Review. European Journal of Pharmacology, 716, 54-60. http://dx.doi.org/10.1016/j.ejphar.2013.03.004

[55] Hoyer, D. and Bartfai, T. (2012) Neuropeptides and Neuropeptide Receptors: Drug Targets and Peptide and Non-Peptide Ligands: A Tribute to Prof. Dieter Seebach. Chemistry and Biodiversity, 9, 2367-2387. http://dx.doi.org/10.1002/cbdv.201200288

[56] Maurer, M., Bader, M., Bas, M., Bossi, F., Cicardi, M., Cugno, M., Howarth, P., Kaplan, A., Kojda, G, Leeb-Lundberg, F., Lötvall, J. and Magerl, M. (2011) New Topics in Bradykinin Research. Allergy, 66, 1397-1406. http://dx.doi.org/10.1111/j.1398-9995.2011.02686.x

[57] Benemei, S., Nicoletti, P., Capone, J.G. and Geppetti, P. (2009) CGRP Receptors in the Control of Pain and Inflammation. Current Opinion in Pharmacology, 9, 9-14. http://dx.doi.org/10.1016/j.coph.2008.12.007

[58] Dam, T.V., Martinelli, B. and Quirio, R. (1990) Autoradiographic Distribution of Brain Neurokinin-1/Substance P Receptors Using a Highly Selective Ligand $\left[{ }^{3} \mathrm{H}\right]-\left[\mathrm{Sar}^{9}\right.$, Met $\left.\left(\mathrm{O}_{2}\right)^{11}\right]$-Substance P. Brain Research, 531, 333-337. http://dx.doi.org/10.1016/0006-8993(90)90796-E

[59] Tousignant, C., Guillemette, G., Drapeau, G., Telemaque, S., Dion, S. and Regoli, D. (1990) ${ }^{125} \mathrm{I}-\mathrm{BH}\left[\mathrm{Sar}^{9}, \mathrm{Met}\left(\mathrm{O}_{2}\right)^{11}\right]-\mathrm{SP}$, a New Selective Ligand for the NK-1 Receptor in the Central Nervous System. Brain Research, 524, 263-270. http://dx.doi.org/10.1016/0006-8993(90)90700-L

[60] Bell, I.M., Gallichio, S.N., Stump, C.A., Bruno, J.G., Fan, H., Gantert, L.T., Hostetler, E.D., Kemmerer, A.L., McWherter, M., Moore, E.L., Mosser, S.D., Purcell, M.L., Riffel, K., Salvatore, C.A., Sanabria-Bohorquez, S., Staas, D.D., White, R.B., Williams, M., Zartmann, C.B., Cook, J.J., Hargreaves, R.J., Kane, S.A., Graham, S.L. and Selnick, H.G. (2013) [ $\left.{ }^{11} \mathrm{C}\right]-\mathrm{MK}-4232:$ The First Positron Emission Tomography Tracer for the Calcitonin Gene-Related Peptide Receptor. ACS Medicinal Chemistry Letters, 4, 863-868. http://dx.doi.org/10.1021/ml400199p

[61] Lord, J.A., Waterfield, A.A., Hughes, J. and Kosterlitz, H.W. (1977) Endogenous Opioid Peptides: Multiple Agonists and Receptors. Nature, 267, 495-499. http://dx.doi.org/10.1038/267495a0

[62] Simon, E.J., Hiller, J.M. and Edelman, I. (1973) Stereospecific Binding of the Potent Narcotic Analgesic (3H) Etorphine to Rat Brain Homogenate. Proceedings of the National Academy of Sciences of the United States of America, 70, 1947-1951. http://dx.doi.org/10.1073/pnas.70.7.1947

[63] Pert, C.B. and Snyder, S.H. (1973) Opiate Agonists and Antagonists Discriminated by Receptor Binding in Brain. Science, 179, 1011-1014. http://dx.doi.org/10.1126/science.179.4077.1011

[64] Terenius, L. (1973) Stereospecific Interaction between Narcotic Analgesics and a Synaptic Plasma Membrane Fraction of Rat Cerebral Cortex. Acta Pharmacologica et Toxicologica, 32, 317-320. http://dx.doi.org/10.1111/j.1600-0773.1973.tb01477.x

[65] Bunzow, J.R., Saez, C., Mortrud, M., Bouvier, C., Williams, J.T., Low, M. and Grandy, D.K. (1994) Molecular Cloning and Tissue Distribution of a Putative Member of the Rat Opioid Receptor Gene Family that Is Not a $\mu, \delta$ or $\kappa$ Opioid Receptor Type. FEBS Letters, 347, 284-288. http://dx.doi.org/10.1016/0014-5793(94)00561-3

[66] Kieffer, B.L., Befort, K., Gaveriaus-Ruff, C. and Hirth, C.G. (1992) The Delta-Opioid Receptor: Isolation of a cDNA by Expression Cloning and Pharmacological Characterization. Proceedings of the National Academy of Sciences of the United States of America, 89, 12048-12052. http://dx.doi.org/10.1073/pnas.89.24.12048

[67] Evans, C.J., Keith, D.E., Morrison, H., Magendzo, K. and Edwards, R.H. (1992) Cloning of a Delta Opioid Receptor by Functional Expression. Science, 258, 1952-1955. http://dx.doi.org/10.1126/science.1335167

[68] Davis, M.P. and Pasternak, G.W. (2009) Opioid Receptors and Opioid Pharmacodynamics.In: Davis, M.P., Glare, P.A., Hardy, J. and Quingley, C., Eds., Chapter 1, Opioids in Cancer Pain, 2nd Edition, Oxford University Press, Oxford, $1-24$.

[69] Manglik, A., Kruse, A., Kobilka, T.S., Thian, F.S., Mathiesen, J.M., Sunahara, R.K., Pardo, L., Weis, W.I., Kobilka, B.K. and Granier, S. (2012) Crystal Structure of the $\mu$-Opioid Receptor Bound to a Morphinan Antagonist. Nature, 485, 321-327. http://dx.doi.org/10.1038/nature10954

[70] Stein, C. (1995) Mechanism of Disease: The Control of Pain in Peripheral Tissue by Opioids. The New England Journal of Medicine, 332, 1685-1690. http://dx.doi.org/10.1056/NEJM199506223322506 
[71] Ingram, S.L. and Williams, J.T. (1994) Opioid Inhibition of $\mathrm{I}_{\mathrm{h}}$ via Adenylyl Cyclase. Neuron, 13, 179-186. http://dx.doi.org/10.1016/0896-6273(94)90468-5

[72] Ikeda, K., Kobayashi, T., Ichikawa, T, Kumanishi, T., Niki, H. and H., Yano, R. (2001) The Untranslated Region of $\mu$-Opioid Receptor mRNA Contributes to Reduced Opioid Sensitivity in CXBK Mice. The Journal of Neuroscience, 21, 1334-1339.

[73] Law, P.Y., Wong, Y.H. and Loh, H.H. (2000) Molecular Mechanisms and Regulation of Opioid Receptor Signaling. Annual Review of Pharmacology and Toxicology, 40, 389-430. http://dx.doi.org/10.1146/annurev.pharmtox.40.1.389

[74] Ishikawa, M. and Hashimoto, K. (2010) The Role of Sigma-I Receptors in the Pathophysiology of Neuropsychiatric Diseases. Journal of Receptor, Ligand and Channel Research, 3, 25-36.

[75] Hayashi, T. and Su, T.P. (2007) Sigma-1 Receptor Chaperones at the ER-Mitochondrion Interface Regulates Ca ${ }^{2+}$ Sig- $^{-}$ naling and Cell Survival. Cell, 131, 596-610. http://dx.doi.org/10.1016/j.cell.2007.08.036

[76] Gundlach, A.L., Largent, B.L. and Snyder, S.H. (1986) Autoradiographic localization of Sigma Receptor Binding Sites in Guinea Pig and Rat Central Nervous System with (+)3H-3-(3-Hydroxyphenyl)-N-(1-propyl)piperidine. The Journal of Neuroscience, 6, 1757-1770.

[77] Quirion, R., Chicheportiche, R., Contreras, P.C., Johnson, K.M., Lodge, D., Tam, S.W., Woods, J.H. and Zukin, S.R. (1987) Classification and Nomenclature of Phencyclidine and Sigma Receptor sites. Trends in Neurosciences, 10, 444446. http://dx.doi.org/10.1016/0166-2236(87)90094-4

[78] Moebius, F.F., Reiter, R.J., Hanner, M. and Glossmann, H. (1997) High Affinity of Sigma ${ }_{1}$ Binding Sites for Sterol Isomerization Inhibitors: Evidence for a Pharmacological Relationship with the Yeast Sterol $\mathrm{C}_{8}-\mathrm{C}_{7}$ Isomerase. British Journal of Pharmacology, 121, 1-6. http://dx.doi.org/10.1038/sj.bjp.0701079

[79] Law, P.Y., Loh, H.H. and Li, C.H. (1979) Properties and Localization of Endorphin Receptor in Rat Brain. Proceedings of the National Academy of Sciences of the United States of America, 76, 5455-5459. http://dx.doi.org/10.1073/pnas.76.11.5455

[80] Czlonkowski, A., Costa, T., Przewlocki, R., Pasi, A. and Herz, A. (1983) Opiate Receptor Binding Sites in Human spinal Cord. Brain Research, 267, 392-396. http://dx.doi.org/10.1016/0006-8993(83)90897-1

[81] Besse, D., Lombard, M.C., Zajac, .M., Roques, B.P. and Besson, J.M. (1990) Pre- and Postsynaptic Distribution of $\mu, \delta$ and $\kappa$ Opioid Receptors in the Superficial Layers of the Cervical Dorsal Horn of the Rat Spinal Cord. Brain Research, 521, 15-22. http://dx.doi.org/10.1016/0006-8993(90)91519-M

[82] Faull, R.L.M. and Villinger, J.W. (1987) Opiate Receptors in the Human Spinal Cord: A Detailed Anatomical Study Comparing the Autoradiographic Localization of $\left[{ }^{3} \mathrm{H}\right]$ Diprenorphine Binding Sites with the Laminar Pattern of Substance P, Myelin and Nissl Staining. Neuroscience, 20, 395-407. http://dx.doi.org/10.1016/0306-4522(87)90100-X

[83] Hiller, J.M. and Fan, L.Q. (1996) Laminar Distribution of the Multiple Opioid Receptors in Human Cerebral Cortex. Neurochemical Research, 21, 1333-1345.

[84] Kitchen, I., Slowe, S.J., Matthes, H.W.D. and Kieffer, B. (1997) Quantitative Autoradiographic Mapping of $\mu$-, $\delta$ - and $\kappa$-Opioid Receptors in Knockout Mice Lacking the $\mu$-Opioid Receptor Gene. Brain Research, 778, 73-88. http://dx.doi.org/10.1016/S0006-8993(97)00988-8

[85] Takemori, A.E. and Portoghese, P.S. (1985) Affinity Labels for Opioid Receptors. Annual Review of Pharmacology and Toxicology, 25, 193-223. http://dx.doi.org/10.1146/annurev.pa.25.040185.001205

[86] Broadbear, J.H., Sumpter, T.L., Burke, T.F., Husbands, S.M., Lewis, J.W., Woods, J.H. and Traynor, T.F. (2000) Methocinnamox Is a Potent, Long-Lasting, and Selective Antagonist of Morphine Mediated Antinociception in the Mouse: Comparison with Clocinnamox, $\beta$-Funaltrexamin, and $\beta$-Chlornatrexamine. Journal of Pharmacology and Experimental Therapeutics, 294, 933-940.

[87] Hahn, F.F. and Pasternak, G.W. (1981) Naloxazine, a Potent, Long-Lasting Inhibitor of Opiate Binding Sites. Life Sciences, 31, 1385-1388. http://dx.doi.org/10.1016/0024-3205(82)90387-3

[88] Porthogese, P.S., Lipkowski, A.W. and Takemori, A.E. (1987) Binaltorphimine and Nor-Binaltorphimine, Potent and Selective $\kappa$ Opioid Receptor Antagonists. Life Science, 40, 1287-1292. http://dx.doi.org/10.1016/0024-3205(87)90585-6

[89] Neumann, G., Erhardt, W., Oberhuber, B., Fritsch, R. and Blumel, G. (1980) A New Highly Potent and Short-Acting Analgesic, Carfentanyl (R 33799), in Combination with the Hypnotic Agent, Etomidat (R 26490), as a Method of Anesthesia in Guinea Pigs. Zeitschrift für die gesamte experimentelle Medizin einschliesslich experimenteller Chirurgie, 177, 135-143.

[90] Frost, J.J., Douglass, K.H., Mayberg, H.S., Dannals, R.F., Links, J.M., Wilson, A.A., Ravert, H.T., Crozier, W.C. and Wagner, H.N. (1989) Multicompartmental Analysis of $\left[{ }^{11} \mathrm{C}\right]$-Carfentanil Binding to Opiate Receptors in Humans Measured by Positron Emission Tomography. Journal of Cerebral Blood Flow \& Metabolism, 9, 398-409.

http://dx.doi.org/10.1038/jcbfm.1989.59 
[91] Guterstam, J., Jayram-Lindström, N., Cervenka, S., Frost, J.J. and Farde, L. (2013) Effects of Amphetamine on the Human Brain Opioid System-A Positron Emission Tomography Study. The International Journal of Neuropsychopharmacology, 16, 763-769. http://dx.doi.org/10.1017/S1461145712000818

[92] Burke, T.R., Rice, K.C. and Pert, C.B. (1985) Probes for Narcotic Receptor Mediated Phenomena. II. Synthesis of 17-Methyl and 17-Cyclopropylmethyl-3,14-Dihydroxy-4,5Alpha-Epoxy-6-Beta-Fluoromorphinans (Foxy and Cyclofoxy) as Models of Opioid Ligands Suitable for Positron Emission Transaxial Tomography. Heterocycles, 23, 99-106.

[93] Kling, M., Borg, L., Zametkin, A., Schluger, J., Carson, R., Matochik, J., Maslansky, R., Khuri, R., Wells, A., Lambert, S., Kreuter, J., Herscovitch, P., Eckelman, W., Rice, K., Ho, A. and Kreek, M.J. (1997) Opioid Receptor Binding in Methadone Maintained Former Heroin Addicts by PET Imaging Using [18F]Cyclofoxy. NIDA Research Monograph, 174, 120.

[94] Pert, C.B., Danks, J.A., Channing, M.A., Eckelman, W.C., Larson, S.M., Bennett, J.M., Burke Jr., T.R. and Rice, K.C. (1984) 3-[18F]Acetylcyclofoxy: A Useful Probe for the Visualization of Opiate Receptors in Living Animals. FEBS Letters, 177, 281-286. http://dx.doi.org/10.1016/0014-5793(84)81300-9

[95] Theodore, W.H., Carson, R.E., Andreasen, P., Zametkin, A., Blasberg, R. and Leiderman, D.B. (1992) PET Imaging of Opiate Receptor Binding in Human Epilepsy Using [18F]Cyclofoxy. Epilepsy Research, 13, 129-139. http://dx.doi.org/10.1016/0920-1211(92)90068-5

[96] Lever, J.R. (2007) PET and SPECT Imaging of the Opioid System: Receptors Radioligands and Avenues for Drug Discovery and Development. Current Pharmaceutical Design, 13, 33-49. http://dx.doi.org/10.2174/138161207779313821

[97] Naylor, M.R., Seminowicz, D.A., Somers, T.J. and Keefe, F.J. (2012) Pain Imaging. In: Moore, R.J., Ed., Chapter 27, Handbook of Pain and Palliative Care, Springer Science Buisiness Media, LLC, New York, Dordrecht, Heidelberg, London, 439-467.

[98] Poisnel, G., Queslati, F., Dhilly, M., Delamare, J., Perrio, C., Debruyne, D. and Barre, L. (2008) [ ${ }^{11}$ C]-MeJDTic: A Novel Radioligand for $\kappa$-Opioid Receptor Positron Emission Tomography Imaging. Nuclear Medicine and Biology, 35, 561-569. http://dx.doi.org/10.1016/j.nucmedbio.2008.02.010

[99] Goody, R.J., Oakley, S.M., Filliol, D., Kieffer, B.L. and Kitchen, I. (2002) Quantitative Autoradiographic Mapping of Opioid Receptors in the Brain of $\delta$-Opioid Receptor Gene Knockout Mice. Brain Research, 945, 9-19. http://dx.doi.org/10.1016/S0006-8993(02)02452-6

[100] Endres, C.J., Bencherif, B., Hilton, J., Madar, I. and Frost, J.J. (2003) Quantification of Brain $\mu$-Opioid Receptors with $\left[{ }^{11} \mathrm{C}\right]$ Carfentanil: Reference-Tissue Methods. Nuclear Medicine and Biology, 30, 177-186. http://dx.doi.org/10.1016/S0969-8051(02)00411-0

[101] Hammers, A. and Lingford-Hughes, A. (2006) Opioid Imaging. Neuroimaging Clinics of North America, 16, 529-552. http://dx.doi.org/10.1016/j.nic.2006.06.004

[102] Jones, R.M. and Porthogese, P.S. (2000) 5'-Guanidinonaltrindole, a Highly Selective and Potent $\kappa$-Opioid Receptor Antagonist. European Journal of Pharmacology, 396, 49-52. http://dx.doi.org/10.1016/S0014-2999(00)00208-9

[103] Talbot, P.S., Narendran, R., Butelman, E.R., Huang, Y., Ngo, K., Slifstein, M., Martinez, D., Laruelle, M. and Hwang, D.R. (2005) ${ }^{11}$ C-GR103545, a Radiotracer for Imaging $\kappa$ Opioid Receptors in Vivo with PET: Synthesis and Evaluation in Baboons. Journal of Nuclear Medicine, 46, 484-494.

[104] Thomas, J.B., Atkinson, R.N., Rothman, R.B., Fix, S.E., Mascarella, S.W., Vinson, N.A., Xu, H., Dersch, C.M., Lu, Y.F., Cantrell, B.E., Zimmerman, D.M. and Carroll, F.I. (2001) Identifictaion of the First Trans-(3R, 4R)-Dimethyl-4(3-Hydroxyphenyl) Piperidine Derivative to Possess Highly Potent and Selective Opioid $\kappa$ Receptor Antagonist Activity. Journal of Medicinal Chemistry, 44, 2687-2690. http://dx.doi.org/10.1021/jm015521r

[105] Thomas, J.B., Atkinson, R.N., Vinson, N.A., Catanzaro, J.L., Peretta, C.L., Fix, S.E., Mascarella, S.W., Rothman, R.B., Xu, H., Dersch, C.M., Lu, Y.F., Cantrell, B.E., Zimmerman, D.M. and Carroll, F.I. (2003) Identification of (3R)-7Hydroxy-N-((1S)-1-\{[(3R, 4R)-4-(3-Hydroxyphenyl)-3,4-Dimethyl-1-Piperidinyl]-2-Methylpropyl-1,2,3,4-Tetrahydro-3Isoquinolinecarboxamide as a Novel Potent and Selective Opioid $\kappa$ Receptor Antagonist. Journal of Medicinal Chemistry, 46, 3127-3137. http://dx.doi.org/10.1021/jm030094y

[106] Munro, T.A., Berry, L.M., Van’t Veer, A., Beguin, C., Carrol Ivy, F., Zhao, Z., Carlezon, W.A. and Cohen, B.M. (2012) Long-Acting $\kappa$ Opioid Antagonists Nor-BNI, GNTI and JDTic: Pharmacokinetics in Mice and Lipophilicity. BMC Pharmacology, 12, 5. http://dx.doi.org/10.1186/1471-2210-12-5

[107] Kim, S.J., Zheng, M.Q., Nabulsi, N., Labarree, D., Ropchan, J., Morris, E.D., Najafzadeh, S., Carson, R.E., Huang, Y. and Morris, E.D. (2013) Determination of the in Vivo Selectivity of a New $\kappa$ Opioid Receptor Antagonist PET Tracer LY2795050 in the Rhesus Monkey. Journal of Nuclear Medicine, 54, 1668-1674. http://dx.doi.org/10.2967/jnumed.112.118877

[108] Emson, P.C., Goedert, M., Horsfield, P.M., Riou, F. and St. Pierre, S. (1982) The Regional Distribution and Chromatographic Characterization of Neurotensin-Like Immunoreactivity in the Rat Central Nervous System. Journal of Neu- 
rochemistry, 38, 992-999. http://dx.doi.org/10.1111/j.1471-4159.1982.tb05340.x

[109] Mai, J., Triepel, J. and Metz, J. (1987) Neurotensin in the Human Brain. Neuroscience, 22, 499-524. http://dx.doi.org/10.1016/0306-4522(87)90349-6

[110] Pelaprat, D. (2006) Interactions between Neurotensin Receptors and G Proteins. Peptides, 27, 2476-2487. http://dx.doi.org/10.1016/j.peptides.2006.04.027

[111] Alshoukr, F., Prignon, A., Brans, L., Jallane, A., Mendes, S., Talbot, J.N., Tourwe, D., Barbet, J. and Gruaz-Guyon, A. (2011) Novel DOTA-Neurotensin Analogues for 111 In Scintigraphy and 68Ga PET Imaging of Neurotensin ReceptorPositive Tumors. Bioconjugate Chemistry, 22, 1374-1385. http://dx.doi.org/10.1021/bc200078p

[112] Betancur, C., Canton, M., Burgos, A., Labeeuw, B., Gully, D., Rostene, W. and Pelaprat, D. (1998) Characterization of Binding Sites of a New Neurotensin Receptor Antagonist $\left[{ }^{3} \mathrm{H}\right] \mathrm{SR}$ 142948A, in the Rat Brain. European Journal of Pharmacology, 343, 67-77. http://dx.doi.org/10.1016/S0014-2999(97)01510-0

[113] Taylor, G.M., Meeran, K., O’Shea, D., Smith, D.M., Ghatei, M.A. and Bloom, S.R. (1996) Adrenomedullin Inhibits Feeding in the Rat by a Mechanism Involving Calcitonin Gene-Related Peptide Receptors. Endocrinology, 137, 32603264. http://dx.doi.org/10.1210/endo.137.8.8754748 http://dx.doi.org/10.1210/en.137.8.3260

[114] Hinson, J.P., Kapasd, S. and Smith, D.M. (2000) Adrenomedullin, a Multifunctional Regulatory Peptide. Endocrine Reviews, 21, 138-167. http://dx.doi.org/10.1210/er.21.2.138 http://dx.doi.org/10.1210/edrv.21.2.0396

[115] Privitera, P.J., Beckstead, R.M., Yates, P. and Walgren, R. (2003) Autoradiographic Localization of $\left[{ }^{125} \mathrm{I}-\mathrm{Tyr}{ }^{0}\right]$ Bradykinin Binding Sites in Brains of Wistar-Kyoto and Spontaneously Hypertensive Rats. Cellular and Molecular Neurobiology, 23, 805-815. http://dx.doi.org/10.1023/A:1025061205355

[116] Lopes, P., Kar, S., Chretien, L., Regoli, D., Quirion, R. and Couture, R. (1995) Quantitative Autoradiographic Localization of $\left[{ }^{125} \mathrm{I}_{-} \mathrm{Tyr}^{8}\right]$ Bradykinin Receptor Binding Sites in the Rat Spinal Cord Effects of Neonatal Capsaicin, Noradrenergic Deafferentiation, Dorsal Rhizotomy and Peripheral Axotomy. Neuroscience, 68, 867-881. http://dx.doi.org/10.1016/0306-4522(95)00161-B

[117] Saffroy, M., Torrens, Y., Glowinski, J. and Beaujouan, J.C. (2001) Presence of $\mathrm{NK}_{2}$ Binding Sites in the Rat Brain. Journal of Neurochemistry, 79, 985-996. http://dx.doi.org/10.1046/j.1471-4159.2001.00633.x

[118] Dam, T.V., Escher, E. and Quirion, R. (1990) Visualization of Neurokinin-3 Receptor Sites in Rat Brain Using the Highly Selective Ligand $\left[{ }^{3} \mathrm{H}\right]$ Senktide. Brain Research, 506, 175-179.http://dx.doi.org/10.1016/0006-8993(90)91218-6

[119] Buhler, A.V., Proudfit, H.K. and Gebhart, G.F. (2008) Neurotensin-Produced Antinociception in the Rostral Ventromedial Medulla Is Partially Mediated by Spinal Cord Norepinephrine. Pain, 135, 280-290. http://dx.doi.org/10.1016/j.pain.2007.06.010

[120] Smith, D.J., Hawranko, A.A., Monroe, P.J., Gully, D., Urban, M.O., Craig, C.R., Smith, J.P. and Smith, D.L. (1997) Dose-Dependent Pain-Facilitatory and -Inhibitory Actions of Neurotensin Are Revealed by SR48692, a Nonpeptide Neurotensin Antagonist: Influence on the Antinociceptive Effect of Morphine. Journal of Pharmacology and Experimental Therapeutics, 282, 899-908.

[121] Neubert, M.J., Kincaid, W. and Heinricher, M.M. (2004) Nociceptive Facilitating Neurons in the Rostral Ventromedial Medulla. Pain, 110, 158-165. http://dx.doi.org/10.1016/j.pain.2004.03.017

[122] Kasckow, J. and Nemeroff, C.B. (1991) The Neurobiology of Neurotensin: Focus on Neurotensin-Dopamine Interactions. Regulatory Peptides, 36, 153-164. http://dx.doi.org/10.1016/0167-0115(91)90053-J

[123] Mazella, J., Botto, J.M., Guillemare, E., Coppola, T., Sarret, P. and Vincent, J.P. (1996) Structure, Functional Expression, and Cerebral Localization of the Levocabastine-Sensitive Neurotensin/Neuromedin N Receptor from Mouse Brain. Journal of Neuroscience, 16, 5613-5620.

[124] Schotte, A., Leysen, J.E. and Laduron, P.M. (1986) Evidence for a Displaceable Non Specific $\left[{ }^{3} H\right]$ Neurotensin Binding Site in Rat Brain. Naunyn-Schmiedeberg's Archives of Pharmacology, 333, 400-405. http://dx.doi.org/10.1007/BF00500016

[125] St-Gelais, F., Jomphe, C. and Trudeau, L.E. (2006) The Role of Neurotensin in Central Nervous System Pathophysiology: What Is the Evidence? Journal of Psychiatry \& Neuroscience, 31, 229-245.

[126] Hermey, G. (2009) The Vsp10p-Domain Receptor Family. Cellular and Molecular Life Sciences, 66, 2677-2689. http://dx.doi.org/10.1007/s00018-009-0043-1

[127] Mazella, J. (2001) Sortilin/Neurotensin Receptor 3: A New Tool to Investigate Neurotensin Signaling and Cellular Trafficking? Cellular Signalling, 13, 1-6. http://dx.doi.org/10.1016/S0898-6568(00)00130-3

[128] Petersen, C.M., Nielsen, M.S., Nykjaer, A., Jacobseen, L., Tommerup, N., Rasmussen, H.H., Roigaard, H., Gliemann, J., Madsen, P. and Moestrup, S.K. (1997) Molecular Identification of a Novel Candidate Sorting Receptor Purified 
from Human Brain by Receptor-associated Protein Affinity Chromatography. Journal of Biological Chemistry, 272, 3599-3605. http://dx.doi.org/10.1074/jbc.272.6.3599

[129] Martin, S., Vincent, J.P. and Mazella, J. (2003) Involvement of the Neurotensin Receptor-3 in the Neurotensin Iduced Migration of Human Microglia. Journal of Neuroscience, 23, 1198-1205.

[130] Wu, Z., Martinez-Fong, D., Tredaniel, J. and Forgez, P. (2013) Neurotensin and Its High Affinity Receptor 1 as a Potential Pharmacological Target in Cancer Therapy. Frontiers in Endocrinology, 3, Article 184/1-9. http://dx.doi.org/10.3389/fendo.2012.00184

[131] Held, C., Plomer, M., Hübner, H., Meltretter, J., Pischetsrieder, M. and Gmeiner, P. (2013) Development of a Metabolically Stable Neurotensin Receptor 2 (NTS2) Ligand. ChemMedChem, 8, 75-81. http://dx.doi.org/10.1002/cmdc.201200376

[132] Held, C., Hübner, H., Kling, R., Nagel, Y.A., Wennemers, H. and Gmeiner, P. (2013) Impact of the Proline Residue on Ligand Binding of Neurotensin Receptor2 (NTS2)-Selective Peptide-Peptoid Hybrids. ChemMed Chem., 8, $772-778$. http://dx.doi.org/10.1002/cmdc.201300054

[133] Maschauer, S., Einsiedel, J., Hocke, C., Hübner, H., Kuwert, T., Gmeiner, P. and Prante, O. (2010) Synthesis of a 68Ga-Labeled Peptoid-Peptide Hybrid for Imaging of Neurotensin Receptor Expression in Vivo. ACS Medicinal Chemistry Letters, 1, 224-228.http://dx.doi.org/10.1021/ml1000728

[134] Maschauer, S., Ruckdeschl, T., Tripal, P., Haubner, R., Einsiedel, J., Hübner, H., Gmeiner, P., Kuwert, T. and Prante, O. (2014) In Vivo Monitoring of the Antiangiogenic Effect of Neurotensin Receptor-Mediated Radiotherapy by Small-Animal Positron Emission Tomography: A Pilot Study. Pharmaceuticals, 7, 464-481. http://dx.doi.org/10.3390/ph7040464

[135] Gully, D., Canton, M., Boigegrain, R., Jeanjean, F., Molimard, J.C., Poncelet, M., Gueudet, C., Heaulme, M., Leyris, R., Brouard, A., Pelaprat, D., Labbe-Jullie, C., Mazella, J., Soubrie, P., Maffrand, J.P., Rostene, W., Kitabgi, P. and Le Fur, G. (1993) Biochemical and Pharmacological Profile of a Potent and Selective Nonpeptide Antagonist of the Neurotensin Receptor. Proceedings of the National Academy of Sciences of the United States of America, 90, 65-69. http://dx.doi.org/10.1073/pnas.90.1.65

[136] Gully, D., Labeeuw, B., Boigegrain, R., Oury-Donat, F., Bachy, A., Poncelet, M., Steinberg, R., Suaud-Chagny, M.F., Santucci, V., Vita, N., Pecceu, F., Labbe-Jullie, C., Kitabgi, P., Soubrie, P., Le Fur, G. and Maffrand, J.P. (1997) Biochemical and Pharmacological Activities of SR 142948A, a New Potent Neurotensin Receptor Antagonist. Journal of Pharmacology and Experimental Therapeutics, 280, 802-812.

[137] Luo, G., Chen, L., Civiello, R., Pin, S.S., Xu, C., Kostich, W., Kelley, M., Conway, C.M., Macor, J.E. and Dubowchik, G.M. (2012) Calcitonin Gene-Related Peptide Receptor Antagonist. Bioorganic \& Medicinal Chemistry Letters, 22, 2917-2921. http://dx.doi.org/10.1016/j.bmcl.2012.02.065

[138] Durham, P.L. (2008) Inhibition of Calcitonin Gene-Related Peptide Function: Promisingstrategy for Treating Migraine. Headache, 48, 1269-1275. http://dx.doi.org/10.1111/j.1526-4610.2008.01215.x

[139] Ho, T.W., Edvinsson, L. and Goadsby, P.J. (2010) CGRP and Its Receptor Provide New Insights into Migraine Pathophysiology. Nature Reviews Neurology, 6, 573-582. http://dx.doi.org/10.1038/nrneurol.2010.127

[140] Eftekhari, S. and Edvinsson, L. (2010) Possible Sites of Action of the New Calcitonin Gene-Related Peptide Receptor Antagonist. Therapeutic Advances in Neurological Disorders, 3, 369-378.

[141] Edvinsson, L., Mc Culloch, J., Kingman T. and Uddman, R. (1986) On the Functional Role of Trigemino-Cerebral Circulation. In: Owman, C. and Hardebo, J.E., Eds., Neural Regulation of Cerebral Circulation of the Cerebral Circulation, Elsevier Science, Amsterdam, 407-418.

[142] Markowitz, S., Saito, K. and Moskowitz, M.A. (1987) Neurogenically Mediated Leakage of Plasma Protein Occurs from Blood Vessels in Dura Mater but Not Brain. Journal of Neuroscience, 7, 4129-4136.

[143] Moore, E.I. and Salvatore, C.A. (2012) Targeting a Family B GPCR/RAMP Receptor Complex: CGRP Receptor Antagonists and Migraine. British Journal of Pharmacology, 166, 66-78. http://dx.doi.org/10.1111/j.1476-5381.2011.01633.x

[144] Mc Latchie, L.M., Fraser, N.J., Main, M.J., Wise, A., Brown, J., Thompson, N., Solari, R., Lee, M.G. and Ford, S.M. (1998) RAMPs Regulate the Transport and Ligand Specifity of the Calcitonin-Receptor-Like Receptor. Nature, 393, 333-339. http://dx.doi.org/10.1038/30666

[145] Buhlmann, N., Leuthauser, K., Muff, R., Fischer, J. and Bonn, W. (1999) A Receptor Activity Protein RAMP2-Dependent Adrenomedullin Receptor Is a Calcitonin Gene-Related Peptide Receptor When Coexpressed with Human RAMP1. Endocrinology, 140, 2883-2890. http://dx.doi.org/10.1210/en.140.6.2883 http://dx.doi.org/10.1210/endo.140.6.6783

[146] Evans, C.J., Keith, D.E., Morrison, H., Magendzo, K. and Edwards, R.H. (1992) Cloning of a Delta Opioid Receptor by Functional Expression. Science, 258, 1952-1955. http://dx.doi.org/10.1126/science.1335167 
[147] Alexander, S., Mathie, A. and Peters, J.A. (2011) Guide to Receptors and Channels (GRAC), 5th Edition. British Journal of Pharmacology, 164, S1-S324.

[148] Hay, D.L. and Dickerson, I.M. (2010) The Calcitonin Gene-Related Peptide Family. Springer Science and Business Media B.V., Dodrecht, Heidelberg, London.

[149] Edvinsson, L., Villalon, C.M. and MaasssenVanDenBrink, A. (2012) Basic Mechanisms of Migraine and Its Acute Treatment. Pharmacology \& Therapeutics, 136, 319-333. http://dx.doi.org/10.1016/j.pharmthera.2012.08.011

[150] Rudolf, K., Eberlein, W., Engel, W., Pieper, H., Entzeroth, M., Hallermayer, G. and Doods, H. (2005) Development of Human Calcitonin Gene-Related Peptide (CGRP) ReceptorAntagonists. 1. Potent and Selective Small Molecule CGRP Angonists. 1-[ $N^{2}$-[3,5-Dibromo- $N$-[[4-(3,4-dihydro-2(1H)-oxoquinazolin-3-yl)-1-piperidinyl]carbonyl]-D-tyrosyl]-Llysyl]-4-(4-pyridinyl)piperazine: The First CGRP Antagonist for Clinical Trials in Acute Migraine. Journal of Medicinal Chemistry, 48, 5921-5931. http://dx.doi.org/10.1021/jm0490641

[151] Quayle, J.M., Bonev, A.D., Brayden, J.E. and Nelson, M.T. (1994) Calcitonin Gene Related Peptide Activated ATP Sensitive K+ Currents in Rabbit Arterial Smooth Muscle via Protein Kinase A. Journal of Physiology, 475, 9-13.

[152] Blankeney, J.S., Reid, R.C., Le, G.T. and Fairlie, D.P. (2007) Nonpeptide Ligands for Peptide Activated G-ProteinCoupled Receptors. Chemical Reviews, 107, 2960-3041. http://dx.doi.org/10.1021/cr050984g

[153] Hostetler, E.D., Joshi, A.D., Sanabria-Bohorquez, S., Fan, H., Zeng, Z., Purcell, M., Gantert, L., Riffel, K., William, M., O’Malley, S., Miller, P., Selnick, H.G., Gallicchio, S.N., Bell, I.M., Salvatore, C., Kane, S.A., Li, C.C., Hargreaves, R., de Groot, T., Bormans, G., van Hecken, A., Derdelinckx, I., de Hoon, J., Reynders, T., Declercq, R., de Lepeleire, I., Kennedy, W.D., Blanchard, R., Marcantonio, E.E., Sur, C., Cook, J.J., van Laere, K. and Evelhoch, J.L. (2013) In Vivo Quantification of Calcitonin Gene Related Peptide (CGRP) Receptor Occupancy by Telcagepant in Rhesus Monkey and Human Brain Using the Positron Emission Tomography (PET)Tracer [ $\left.{ }^{11} \mathrm{C}\right] \mathrm{MK}-4232$. Journal Of Pharmacology and Experimental Therapeutics, 347, 478-486. http://dx.doi.org/10.1124/jpet.113.206458

[154] Mallee, J.J., Salvatore, C.A., LeBourdelles, B., Oliver, K.R., Longmore, J., Koblan, K.S. and Kane, S.A. (2002) Receptor Activity-Modyfying Protein I Determines the Species Selectivity of Nonpeptide CGRP Receptor Antagonists. Journal of Biological Chemistry, 277, 14294-14298. http://dx.doi.org/10.1074/jbc.M109661200

[155] Weiller, C., May, A., Limmroth, V., Jüptner, M., Kaube, H., Schayck, R.V., Coenen, H.H. and Diener, H.C. (1995) Brain Stem Activation in Spontaneous Human Migraine Attacks. Nature Medicine, 1, 658-660. http://dx.doi.org/10.1038/nm0795-658

[156] Olesen, J., Diener, H.C., Husstedt, I.W., Goadsby, P.J., Hall, D., Meier, U., Pollentier, S. and Lesko, L.M. (2004) Calcitonin Gene-Related Peptide Receptor Antagonist BIBN 4096 BS for the Acute Treatment of Migraine. New England Journal of Medicine, 350, 1104-1110. http://dx.doi.org/10.1056/NEJMoa030505

[157] Diener, H.C., Barbanti, P., Dahlöf, C., Reuter, U., Habeck, J. and Podhorna, J. (2010) BI 44370 TA, an Oral CGRP Antagonist for the Treatment of Acute Migraine Attacks: Results from a Phase II Study. Cephalalgia, 31, 573-584. http://dx.doi.org/10.1177/0333102410388435

[158] Degnan, A.P., Chaturvedula, P.V., Conway, C.M., Cook, D.A., Davis, C.D., Denton, R., Han, X., Macci, R., Mathias, N.R., Moench, P., Pin, S.S., Ren, S.X., Schartman, R., Signor, L.J., Thalody, G., Widman, K.A., Xu, C., Macor, J.E. and Dubowchik, G.M. (2008) Discovery of R-4-(8-Fluoro-2-Oxo-1,2-Dihydro-Quinazolin-3 (4H)-yl)-N(3-(7-Methyl1H-indazol-5-yl)propan-2yl) Piperidin-1-Carboxamide (BMS-694153): A Potent Antagonist of the Human Calcitonin Gene Related Peptide Receptor for Migraine with Rapid and Efficient Intranasal Exposure. Journal of Medicinal Chemistry, 51, 4858-4861. http://dx.doi.org/10.1021/jm800546t

[159] Bell, I.M., Gallichio, S.N., Wood, M.R., Quigley, A.G., Stump, C.A., Zartman, C.B., Fay, J.F., Li, C.C., Lynch, J.J., Moore, E.L., Mosser, S.D., Prueksaritanont, T., Regan, C.P., Roller, S., Salvatore, C.A., Kane, S.A., Vacca, J.P. and Selnick, H.G. (2010) Discovery of MK-3207: A Highly Potent Orally Available CGRP Receptor Antagonist. ACS Medicinal Chemistry Letters, 1, 24-29. http://dx.doi.org/10.1021/ml900016y

[160] Bell, I.M., Stump, C.A., Gallichio, S.N., Staas, D.D., Zartmann, C.B., Moore, E.L., Sain, N., Urban, M., Bruno, J.G., Calamari, A., Kemmerer, A.L., Mosser, E.L., Fandozzi, C., White, R.B., Zrada, M.M., Selnick, H.G., Graham, S.L., Vacca, J.P., Kane, S.A. and Salvatore, C.A. (2012) MK-8825: Apotent and Selective CGRP Receptore Antagonist with Good Oral Activity in Rats. Bioorganic \& Medicinal Chemistry Letters, 22, 3941-3945. http://dx.doi.org/10.1016/j.bmcl.2012.04.105

[161] Trabold, R., Erös, C., Zweckenberger, K., Relton, J., Beck, H., Nussberger, J., Müller-Esterl, W., Bader, M., Whalley, E. and Plesnila, N. (2010) The Role of Bradykinin B1 and B2 Receptors for Secondary Brain Damage after Traumatic Brain Injury in Mice. Journal of Cerebral Blood Flow \& Metabolism, 30, 130-139. http://dx.doi.org/10.1038/jcbfm.2009.196

[162] Moreau, M.E., Garbacki, N., Molinaro, G., Brown, N.J., Marceau, F. and Adam, A. (2005) The Kallikrein-Kinin System: Current and Future Pharmacological Targets. Journal of Pharmacological Sciences, 99, 6-38. http://dx.doi.org/10.1254/jphs.SRJ05001X 
[163] Nussberger, J., Cugno, M., Amstutz, C., Cicardi, M., Pellacani, A. and Agostoni, A. (1998) Plasma Bradykinin in Angio-Oedema. Lancet, 351, 1693-1697. http://dx.doi.org/10.1016/S0140-6736(97)09137-X

[164] Camarda, V., Rizzi, A., Calo, G., Wirth, K. and Regoli, D. (2002) Pharmacological Characterization of Novel B Re- $^{2}$ ceptor Ligands. Canadian Journal of Physiology and Pharmacology, 80, 281-286. http://dx.doi.org/10.1139/y02-037

[165] Campos, M.M., Leal, P.C., Yunes, R.A. and Cakixto, J.B. (2006) Non-Peptide Antagonists for Kinin B ${ }_{1}$ Receptors: New Insights into Their Therapeutic Potential for the Management of Inflammation and Pain. Trends in Pharmacological Sciences, 27, 646-651. http://dx.doi.org/10.1016/j.tips.2006.10.007

[166] Raidoo, D.M. and Bhoola, K.D. (1997) Kinin Receptors on Human Neurones. Journal of Neuroimmunology, 77, 39-44. http://dx.doi.org/10.1016/S0165-5728(97)00048-9

[167] Cholewinski, A.J., Stevens, G., Mc Dermott, A.M. and Wilkin, G.P. (1991) Identification of B2 Bradykinin Binding Sites on Cutured Cortical Astrocytes. Journal of Neurochemistry, 57, 1456-1458. http://dx.doi.org/10.1111/j.1471-4159.1991.tb08314.X

[168] Noda, M., Kariura, Y., Amano, T., Manago, Y., Nishikawa, K., Aoki, S. and Wada, K. (2003) Expression and Function of Bradykinin Receptors in Microglia. Life Sciences, 72, 1573-1581 http://dx.doi.org/10.1016/S0024-3205(02)02449-9

[169] Murone, C., Paxinos, G., McKinley, M.J., Oldfield, B.J., Müller-Esterl, W., Mendelsohn, F.A.O. and Chai, S.Y. (1997) Distribution of Bradykinin B2 Receptors in Sheep Brain and Spinal Cord Visualized by in Vitro Autoradiography. Journal of Comparative Neurology, 381, 203-218. http://dx.doi.org/10.1002/(SICI)1096-9861(19970505)381:2<203::AID-CNE7>3.0.CO;2-7

[170] Wahl, M., Young, A.R., Edvinsson, L. and Wagner, F. (1983) Effects of Bradykinin on Pial Arteries and Arterioles in Vitro and in Situ. Journal of Cerebral Blood Flow \& Metabolism, 3, 231-237. http://dx.doi.org/10.1038/jcbfm.1983.31

[171] Whalley, E.T. and Wahl, M. (1983) Analysis of Bradykinin Receptor Mediating Relaxation of Cat Cerebral Arteries in Vivo and in Vitro. Naunyn-Schmiedeberg's Archives of Pharmacology, 323, 66-71. http://dx.doi.org/10.1007/BF00498830

[172] Regoli, D., Allogho, S.N., Rizzi, A. and Gobeil, F.J. (1998) Bradykinin Receptors and Their Antagonists. European Journal of Pharmacology, 348, 1-10. http://dx.doi.org/10.1016/S0014-2999(98)00165-4

[173] Cole, S.W. and Lundquist, L.M. (2013) Icatibant for the Treatment of Hereditary Angioedema. Annals of Pharmacotherapy, 47, 49-55. http://dx.doi.org/10.1345/aph.1R423

[174] Lumry, W.R., Li, H.H., Levy, R.J., Potter, P.C., Farkas, H., Moldovan, D., Riedl, M., Craig, T., Bloom, B.J. and Reshef, A. (2011) Randomized Placebo-Controlled Trial of the Bradykinin B2 Receptor Antagonist Icatibant for the Treatment of Acute Attacks of Hereditary Angioedema: FAST-3 Trial. Annals of Allergy, Asthma \& Immunology, 107, 529-537. http://dx.doi.org/10.1016/j.anai.2011.08.015

[175] Aramori, I., Zenkoh, J., Morikawa, N., O’Donnell, N., Asano, M., Nakamura, K., Iwami, M., Kojo, H. and Notsu, Y. (1997) Novel Subtype-Selective Nonpeptide Bradykinin Receptor Antagonists FR167344 and FR 173657. Molecular Pharmacology, 51, 171-176.

[176] Pruneau, D., Paquet, J.L., Luccarini, J.M., Defrene, E., Fouchet, C., Franck, R.M., Loillier, B., Robert, C., Belichard, P., Duclos, H., Cremers, B. and Dodey, P. (1999) Pharmacological Profile of LF 16-0687, a New Potent Non-Peptide Bradykinin B2 Receptor Antagonist. Immunopharmacology, 43, 187-194. http://dx.doi.org/10.1016/S0162-3109(99)00128-9

[177] Asano, M., Inamura, N., Hatori, C., Sawai, H., Fujiwara, T., Katayama, A., Kayakiri, H., Satoh, S., Abe, Y., Inoue, T., Sawada, Y., Nakahara, K., Oku, T. and Okuhara, M. (1997) The Identification of an Orally Active, Nonpeptide Bradykinin B2 Receptor Antagonist, FR173657. British Journal of Pharmacology, 120, 617-624. http://dx.doi.org/10.1038/sj.bjp.0700955

[178] Giardina, G.A.M. and Raveglia, L.F. (1997) Neurokinin-3 Receptor Antagonists. Expert Opinion on Therapeutic Patents, 7, 307-323. http://dx.doi.org/10.1517/13543776.7.4.307

[179] Page, N.M. (2006) Characterization of the Gene Structures, Precursor Processing and Pharmacology of the Endokinin Peptides. Vascular Pharmacology, 45, 200-208. http://dx.doi.org/10.1016/j.vph.2005.08.028

[180] Pennefather, J.N., Lecci, A., Candenas, M.L., Patak, E., Pinto, F.M. and Maggi, C.A. (2004) Tachykinins and Tachykinin Receptors: A Growing Family. Life Sciences, 74, 1445-1463. http://dx.doi.org/10.1016/j.lfs.2003.09.039

[181] Helke, C.J., Krause, J.E., Mantyh, P.W., Couture, R. and Bannon, M.J. (1990) Diversity in Mammalian Tachykinin Peptidergic Neurons: Multiple Peptides, Receptors and Regulatory Mechanisms. FASEB Journal, 4, 1606-1615.

[182] Nussdorfer, G.G. and Malendowicz, L.K. (1998) Role of Tachykinins in the Regulation of the Hypothalamo-PituitaryAdrenal Axis. Peptides, 19, 949-968. http://dx.doi.org/10.1016/S0196-9781(98)00017-5

[183] Wang, Y., Barton, B., Nielsen, P.F. and Conlon, J.M. (1999) Tachykinins (Substance P and Neuropeptide $\gamma$ ) from the 
Brains of the Pallid Sturgeon, Scaphirhynchus Albus and the Paddelfish, Polyodon Spathula (Acipenseriformes). General and Comparative Endocrinology, 116, 21-30. http://dx.doi.org/10.1006/gcen.1999.7348

[184] Morteau, O., Lu, B., Gerard, C. and Gerard, N.P. (2001) Hemokinin Is a Full Agonist at the Substance P Receptor. Nature Immunology, 2, 1088. http://dx.doi.org/10.1038/ni1201-1088

[185] Jones, S., Tucker, K.L., Sage, T., Kaiser, W.J., Barrett, N.E., Lowry, P.J., Zimmer, A., Hunt, S.P., Emerson, M. and Gibbins, J.M. (2008) Peripheral Tachykinins and the Neurokinin Receptor NK1 Are Required for Platelet Thrombus Formation. Blood, 111,605-612. http://dx.doi.org/10.1182/blood-2007-07-103424

[186] Nowicki, M., Ostalska-Nowicka, B., Kondraciuk, B. and Miskowiak, B. (2007) The Significance of Substance P in Physiological and Malignant Haematopoesis. Journal of Clinical Pathology, 60, 749-755. http://dx.doi.org/10.1136/jcp.2006.041475

[187] Page, N.M., Bell, N.J., Gardiner, S.M., Manyonda, I.T., Brayley, K.J., Strange, P.G. and Lowry, P.J. (2003) Characterization of the Endokinins: Human Tachykinins with Cardiovascular Activity. Proceedings of the National Academy of Sciences of the United States of America, 100, 6245-6250. http://dx.doi.org/10.1073/pnas.0931458100

[188] Kurtz, M.M., Wang, R., Clements, M.K., Cascieri, M.A., Austin, C.P., Cunningham, B.R., Chicci, G.G. and Liu, Q.Y. (2002) Identification, Localization and Receptor Characterization of Novel Mammalian Substance p-Like Peptides. Gene, 296, 205-212. http://dx.doi.org/10.1016/S0378-1119(02)00861-2

[189] Debeljuk, L. and Lasaga, M. (1999) Modulation of the Hypothalamo-Pituitary-Gonadal Axis and the Pineal Gland by Neurokinin A, Neuropeptide K and Neuropeptide $\gamma$. Peptides, 20, 285-299. http://dx.doi.org/10.1016/S0196-9781(98)00159-4

[190] Loesch, A., Domer, F.R., Alexander, B. and Burnstock, G. (1993) Electron-Immunocytochemistry of Peptides in Endothelial Cells of Rabbit Cerebral Vessels Following Perfusion with a Perfluorocarbon Emulsion. Brain Research, 611, 333-337. http://dx.doi.org/10.1016/0006-8993(93)90522-O

[191] Metwali, A., Blum, A.M., Ferraris, L., Klein, J.S., Fiocchi, C. and Weinstock, J.V. (1994) Eosinophils within the Healthy or Inflamed Human Intestine Produce Substance P and Vasoactive Intestinal Peptide. Journal of Neuroimmunology, 52, 69-78. http://dx.doi.org/10.1016/0165-5728(94)90164-3

[192] Khawaja, A.M. and Rogers, D.F. (1996) Tachykinins: Receptor to Effector. International Journal of Biochemistry \& Cell Biology, 28, 721-738. http://dx.doi.org/10.1016/1357-2725(96)00017-9

[193] Beaujouan, J.C., Torrens, Y., Saffroy, M. and Glowinski, J. (1986) Quantitative Autoradiographic Analysis of the Distribution of Binding Sites for [125I]-Bolton-Hunter Derivatives of Eledoisin and Substance P in the Rat Brain. Neuroscience, 18, 857-875. http://dx.doi.org/10.1016/0306-4522(86)90105-3

[194] Page, N.M. (2005) New Challenges in the Study of the Mammalian Tachykinins. Peptides, 26, 1356-1368. http://dx.doi.org/10.1016/j.peptides.2005.03.030

[195] Zhang, Y., Lu, L., Furlonger, C., Wu, G.E. and Paige, C.J. (2000) Hemokinin Is a Hematopoetic-Specific Tachykinin that Regulates B Lymphopoiesis. Nature Immunology, 1, 392-397. http://dx.doi.org/10.1038/80826

[196] DeFea, K.A., Vaughan, Z.D., O’Bryan, E.M., Nishijima, D., Dery, O. and Bunnett, N.W. (2000) The Proliferative and Antiapoptotic Effects of Substance P Are Facilitated by Formation of a $\beta$-Arrestin-Dependent Scaffolding Complex. Proceedings of the National Academy of Sciences of the United States of America, 97, 11086-11091. http://dx.doi.org/10.1073/pnas.190276697

[197] Regoli, D., Drapeau, G., Dion, S. and D’Orleans-Juste, P. (1987) Pharmacological Receptors for Substance P and Neurokinins. Life Sciences, 40, 109-117. http://dx.doi.org/10.1016/0024-3205(87)90349-3

[198] DeFelipe, C., Herrero, J.F., O’Brien, J.A., Palmer, J.A., Doyle, C.A., Smith, A.J.H., Laird, J.M.A., Belmonte, C., Cervero, F. and Hunt, S.P. (1998) Altered Nociception, Analgesia and Aggression in Mice Lacking the Receptor for Substance P. Nature, 392, 394-397. http://dx.doi.org/10.1038/32904

[199] Leroy, V., Mauser, P., Gao, Z.L. and Peet, N.P. (2000) Neurokinin Receptor Antagonists. Expert Opinion on Investigational Drugs, 9,735-746. http://dx.doi.org/10.1517/13543784.9.4.735

[200] Belzung, C. (2014) Innovative Drugs to Treat Depression: Did Animal Models Fail to Be Predictive or did Clinical Trials Fail to Detect Effects. Neuropsychopharmacology, 39, 1041-1051. http://dx.doi.org/10.1038/npp.2013.342

[201] McCarson, K.E. and Krause, J.E. (1994) NK-1 and NK-3 Type Tachykinin Receptor mRNA Expression in the Rat Spinal Cord Dorsal Horn Is Increased during Adjuvant or Formalin-Induced Nociception. Journal of Neuroscience, 14, 712-720.

[202] Inquimbert, P. and Scholz, J. (2012) In: Brady, S.T., Siegel, G.J., Albers, R.W., Price, D.L., Benjamins, J., Fisher, S., Hall, A., Bazan, N., Coyle, J. and Sisodia, S., Eds., Pain: Basic Neurochemistry, Principles of Molecular, Cellular and Medical Neurobiology, Academic Press-Elsevier, Waltham, Oxford, 928-941.

[203] Yashpal, K., Dam, T.V. and Quirion, R. (1990) Quantitative Autoradiographic Distribution of Multiple Neurokinin Binding Sites in Rat Spinal Cord. Brain Research, 506, 259-266. 
[204] Greenspan, R.L., Suprenant, V. and Atem, F. (2012) Visualization of Distal Spinal Cord on F-18 FDG PET/CT. Clinical Nuclear Medicine, 37, 137-141. http://dx.doi.org/10.1097/RLU.0b013e31823933a4

[205] Floeth, F.W., Galldiks, N., Eicker, S., Stoffels, G., Herdmann, J., Steiger, H.J., Antoch, G., Rhee, S. and Langen, K.J. (2013) Hypermetabolism in ${ }^{18}$ F-FDG PET Predicts Favorable Outcome Following Decompressive Surgery in Patients with Degenerative cervical Myelopathy. Journal of Nuclear Medicine, 54, 1577-1583. http://dx.doi.org/10.2967/jnumed.112.113183

[206] Wu, C., Zhu, J., Baeslack, J., Zaremba, A., Hecker, J., Kraso, J., Matthews, P.M., Miller, R.H. and Wang, Y.M. (2013) Longitudinal Positron Emission Tomography Imaging for Monitoring Myelin Repair in the Spinal Cord. Annals of Neurology, 74, 688-698. http://dx.doi.org/10.1002/ana.23965

[207] De Paula Faria, D., Copray, S., Sijbesma, J.W.A., Willemsen, A.T.M., Buchpiguel, C.A., Dierchx, R.A.J.O. and deVries, E.F.J. (2014) PET Imaging of Focal Demyelination and Remyelination in a Rat Model of Multiple Sclerosis: Comparison of $\left[{ }^{11} \mathrm{C}\right] \mathrm{MeDAS},\left[{ }^{11} \mathrm{C}\right] \mathrm{CIC}$ and $\left[{ }^{11} \mathrm{C}\right] \mathrm{PIB}$. European Journal of Nuclear Medicine and Molecular Imaging, 41, 995-1003. http://dx.doi.org/10.1007/s00259-013-2682-6

[208] Langlois, X., Wintmolders, C., Te Riele, P., Leyen, J.B. and Jurzak, M. (2001) Detailed Distribution of Neurokinin 3 Receptors in the Rat, Guinea-Pig and Gerbil Brain: A Comparative Autoradiographic Study. Neuropharmacology, 40, 242-253. http://dx.doi.org/10.1016/S0028-3908(00)00149-0

[209] Almeida, T.A., Rojo, J., Nieto, P.M., Hernandez, M., Martin, J.D. and Candenas, M.L. (2004) Tachykinin and Tachykinin Receptors: Structure and Activity Relationships. Current Medicinal Chemistry, 11, 2045-2081. http://dx.doi.org/10.2174/0929867043364748

[210] Rigby, M., O’Donnell, R. and Rupniak, N.M. (2005) Species Differences in Tachykinin Receptor Distribution: Further Evidence that the Substance P (NK1) Receptor Predominates in Human Brain. Journal of Comparative Neurology, 490, 335-353. http://dx.doi.org/10.1002/cne.20664

[211] Quartara, L., Altamura, M., Evangelista, S. and Maggi, C.A. (2009) Tachykinin Receptor Antagonists in Clinical Trials. Expert Opinion on Investigational Drugs, 18, 1843-1864. http://dx.doi.org/10.1517/13543780903379530

[212] Wolfensberger, S.P.A., van Berckel, B.N.M., Airaksinen, A.J., Maruyama, K., Lubberink, M., Boellard, R., Carey, W.D.H., Reddingius, W., Veltman, D.J., Windhorst, A.D., Leysen, J.E. and Lammertsma, A.A. (2009) First Evaluation of $\left[{ }^{11} \mathrm{C}\right] \mathrm{R} 116301$ as an in Vivo Tracer of $\mathrm{NK}_{1}$ Receptors in Man. Molecular Imaging and Biology, 11, 241-245. http://dx.doi.org/10.1007/s11307-009-0204-5

[213] Snider, R.M., Constantine, J.W., Lowe, I.J., Longo, K.P., Lebel, W.S., Woody, H.A., Orozda, S.E., Oesai, M.C., Vinick, F.J., Spencer, R.W. and Hess, H.J. (1991) A Potent Non Peptide Antagonist of the Substance P (NK1) Receptor. Science, 251, 435-437. http://dx.doi.org/10.1126/science.1703323

[214] Dionne, R.A., Max, M.B., Gordon, S.M., Parada, S., Sang, C., Gracely, R.H., Sethna, N.F. and MacLean, D.B. (1998) The Substance P Receptor Antagonist CP-99,994 Reduces Acute Postoperative Pain. Clinical Pharmacology \& Therapeutics, 64, 562-568. http://dx.doi.org/10.1016/S0009-9236(98)90140-0

[215] Gardner, C.J., Armour, D.R., Beattie, D.T., Gale, J.D., Hawcock, A.B., Kilpatrick, G.J., Twissell, D.J. and Ward, P. (1996) GR205171: A Novel Antagonist with High Affinity for the Tachykinin NK 1 Receptor, and Potent Broad Spectrum Antiemetic Activity. Regulatory Peptides, 65, 45-53. http://dx.doi.org/10.1016/0167-0115(96)00071-7

[216] Zamuner, S., Rabiner, E.A., Fernandes, S.A., Bani, M., Gunn, R.N., Gomeni, R., Ratti, E. and Cunningham, V.J. (2012) A Pharmacokinetic PET Study of $\mathrm{NK}_{1}$ Receptor Occupancy. European Journal of Nuclear Medicine and Molecular Imaging, 39, 226-235. http://dx.doi.org/10.1007/s00259-011-1954-2

[217] Kramer, M.S., Cutler, N., Feighner, J., Shrivastava, R., Carman, J., Sramek, J.J., Reines, S.A., Liu, G., Snavely, D., Wyatt-Knowles, E., HaIe, J.J., Mills, S.G., MacCoss, M., Swain, C.J., Harrison, T., Hili, R.G., Hefti, F., Scolnick, E.M., Cascieri, M.A., Chicchi, G.G., Sadowski, S.H., Williams, A.R., Hewson, L., Smith, D., Carlson, E.J., Hargreaves, R.J. and Rupniak, N.M.J. (1998) Distinct Mechanisms for Antidepressant Activity by Blockade of Central Substance P Receptors. Science, 281, 1640-1645. http://dx.doi.org/10.1126/science.281.5383.1640

[218] Rupniak, N.M. and Kramer, M.S. (1999) Discovery of the Antidepressant and Anti-Emetic Efficacy of Substance P Receptor $\left(\mathrm{NK}_{1}\right)$ Antagonists. Trends in Pharmacological Sciences, 20, 485-490. http://dx.doi.org/10.1016/S0165-6147(99)01396-6

[219] Tatersall, F.D., Rycroft, W., Cumberbatch, M., Mason, G., Tye, S., Ber, E., Cascieri, M., Hill, R.G., MacIntyre, D.E. and Hargreaves, R.J. (2000) The Novel NK 1 Receptor Antagonist MK-0869 (L-754,030) and Its Water Soluble Phosphoryl Prodrug, L-758,298, Inhibit Acute and Delayed Cisplatin-Induced Emesis in Ferrets. Neuropharmacology, 39, 652-663. http://dx.doi.org/10.1016/S0028-3908(99)00172-0

[220] Bergström, M., Hargreaves, R.J., Burnes, H.D., Goldberg, M.R., Sciberras, D., Reines, S.A., Petty, K.J., Ögren, M., Antoni, G., Långström, B., Eskola, O., Scheinin, M., Solin, O., Majumdar, A.K., Constanzer, M.L., Battisti, W.P., Bradstreet, T.E., Gargano, C. and Hietala, J. (2004) Human Positron Emission Tomography Studies of Brain Neurokinin 1 Receptor Occupancy by Aprepitant. Biological Psychiatry, 55, 1007-1012. 
http://dx.doi.org/10.1016/j.biopsych.2004.02.007

[221] Solin, O., Eskola, O., Hamill, T.G., Bergmann, J., Lehikoinen, P., Grönroos, T., Forsback, S., Haaparanta, M., Viljanen, T., Ryan, C., Gibson, R., Kieczykowski, G., Hietala, J., Harsgreaves, R. and Burns, H.D. (2004) Synthesis and Characterization of a Potent, Selective, Radiolabelled Substance P Antagonist for NK1 Receptor Quantification: ([ $\left[{ }^{18} \mathrm{~F}\right]$ SPA-RQ). Molecular Imaging \& Biology, 6, 373-384. http://dx.doi.org/10.1016/j.mibio.2004.08.001

[222] Keller, M., Montgomery, S., Ball, W., Morrison, M., Snavely, D., Liu, G., Hargreaves, R., Hietala, J., Lines, C., Beebe,

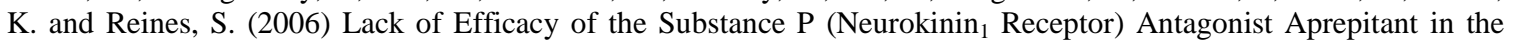
Treatment of Major Depressive Disorder. Biological Psychiatry, 59, 216-223.

http://dx.doi.org/10.1016/j.biopsych.2005.07.013

[223] Fujimura, Y., Yasuno, F., Farris, A., Liow, J.S., Geraci, M., Drevets, W., Pine, D.S., Ghose, S., Lerner, A., Hargreaves, R., Burns, H.D., Morse, C., Pike, V.W. and Innis, R.B. (2009) Decreased Neurokinin-1 (Substance P) Receptor Binding in Patients with Panic Disorder: Positron Emission Tomographic Study with $\left[{ }^{18} \mathrm{~F}\right] \mathrm{SPA}-\mathrm{RQ}$. Biological Psychiatry, 66, 94-97. http://dx.doi.org/10.1016/j.biopsych.2008.12.027

[224] Dorn, C.P., Hale, J.J., MacCoss, M., Mills, S.G., Ladduwahetty, T. and Shah, S.K. (1994) Morpholine and Thiomorpholine Tachikinin Receptor Antagonists. European Patent Application EP 577394 B1.

[225] Dorn, C.P., Hale, J.J., MacCoss, M. and Mills, S.G. (1995) Preparation of Morpholine Tachykinin Receptor Antagonist Prodrugs. PCT Int. Appl.,WO9523798 A1 19950908

[226] Dorn, C.P., Finke, P.E., Hale, J.J., MacCoss, M., Mills, S.G., Shrenik, K., Chambers, M.S., Harrison, T., Ladduwahetty, T. and Williams, B.J. (1995) Morpholine and Thiomorpholine Tachikinin Receptor Antagonists. International Application (Patent Cooperation Treaty), WO 9516679 A1.

[227] Megens, A.A., Ashton, D., Vermeire, J.C., Vermote, P.C., Hens, K.A., Hillen, L.C., Fransen, J.F., Mahieu, M., Heylen, L., Leysen, J.E., Jurzak, M.R. and Janssens, F. (2002) Pharmacological Profile of (2R-trans)-4-[1-[3,5-bis-(trifluoromethyl)benzoyl]-2-(phenylmethyl)-4-piperidinyl]-N-(2,6-dimethylphenyl)-1-acetamide (S)-Hydroxybutanedioate(R116301), an Orally and Centrally Active Neurokinin-1 Receptor Antagonist. Journal of Pharmacology and Experimental Therapeutics, 302, 696-709. http://dx.doi.org/10.1124/jpet.102.034348

[228] Van der Mey, M., Janssens, C.G.M., Janssens, F.E., Jurzak, M., Langois, X., Sommen, F.M., Verreet, B., Windhorst, A.D., Leysen, J.E. and Herscheid, J.D.M. (2005) Synthesis and Biodistribution of $\left[{ }^{11} \mathrm{C}\right] \mathrm{R} 116301$, a Promising PET Ligand for Central NK1 Receptors. Bioorganic \& Medicinal Chemistry, 13, 1579-1586. http://dx.doi.org/10.1016/j.bmc.2004.12.019

[229] Bender, D., Olsen, A.K., Marthi, M.K., Smith, D.F. and Cumming, P. (2004) PET Evaluation of the Uptake of $\mathrm{N}-\left[{ }^{11} \mathrm{C}\right]$ methyl CP-643,051, an $\mathrm{NK}_{1}$ Receptor Antagonist, in the Living Porcine Brain. Nuclear Medicine and Biology, 31, 699-704. http://dx.doi.org/10.1016/j.nucmedbio.2004.03.005

[230] Shimizu, Y., Matsuyama, H., Shiina, T., Takewaki, T. and Furness, J.B. (2008) Tachykinin and Their Functions in the Gastrointestinal Tract. Cellular and Molecular Life Sciences, 65, 295-311. http://dx.doi.org/10.1007/s00018-007-7148-1

[231] Bensaid, M., Faucheux, B.A., Hirsch, E., Agid, Y., Soubrié, P. and Oury-Donat, F. (2001) Expression of Tachykinin NK2 Receptor mRNA in Human Brain. Neuroscience Letters, 303, 25-28. http://dx.doi.org/10.1016/S0304-3940(01)01685-8

[232] Chin, F.T., Morse, C.L., Shetty, H.U. and Pike, V.W. (2006) Automated Radiosynthesis of $\left[{ }^{18}\right.$ F]SPA-RQ for Imaging Human Brain $\mathrm{NK}_{1}$ Receptors with PET. Journal of Labelled Compounds and Radiopharmaceuticals, 49, $17-31$. http://dx.doi.org/10.1002/jlcr.1016

[233] Emonds-Alt, X., Vilain, P., Proietto, V., van Broeck, D., Advenier, C., Naline, E., Neliat, G., Le Fur, G. and Breliere, J.C. (1992) A Potent and Selective Non-Peptide Antagonist of the Neurokinin (NK2) Receptor. Life Sciences, 50, PL101-PL106.

[234] Catalioto, R.M., Criscuoli, M., Cucchi, P., Giachetti, A., Giannoti, D., Giuliani, A., Lecci, A., Lippi, A., Patarcchini, R., Quartara, L., Renzetti, A.R., Tramontana, M., Arcamone, F. and Maggi, C.A. (1998) MEN 11420 (Nepadutant), a Novel Glycosylated Bicyclic Peptide Tachykinin NK2 Receptor Antagonist. British Journal of Pharmacology, 123, 81-91. http://dx.doi.org/10.1038/sj.bjp.0701587

[235] Bai, T.R., Zhou, D., Weir, T., Walker, B., Hegele, R., Hayashi, S., McKay, K., Bondy, G.P. and Fong, T. (1995) Substance P (NK1)-and Neurokinin A (NK2)-Receptor Gene Expression in Inflammatory Airway Disease. American Journal of Physiology, 269, L309-L317.

[236] Louis, C., Stemmelin, J., Boulay, D., Bergis, O., Cohen, C. and Griebel, G. (2008) Additional Evidence for Anxiolyticand Antidepressant-Like Activities of Saredutant (SR48968), an Antagonist at the Neurokinin-2 Receptor in Various Rodent-Models. Pharmacology Biochemistry and Behavior, 89, 36-45. http://dx.doi.org/10.1016/j.pbb.2007.10.020

[237] Emonds-Alt, X., Bichon, D., Ducoux, J.P., Heaulme, M., Miloux, B., Poncelet, M., Proietto, V., Van Broeck, D., Vilain, P., Neliat, G., Soubrie, P., Le Fur, G. and Breliere, J.C. (1995) SR 142801, the First Potent Non-Peptide Antagon- 
ist of the Tachykinin NK3 Receptor. Life Sciences, 56, PL27-PL32.

[238] Sarau, H.M., Griswold, D.E., Potts, W., Foley, J.J., Schmidt, D.B., Webb, E.F., Martin, L.D., Brawner, M.E., Elshourbagy, N.A., Medhurst, A.D., Giardina, G.A. and Hay, D.W. (1997) Nonpeptide Tachykinin Receptor Antagonists: I. Pharmacological and Pharmacokinetic Characterization of SB 223412, a Novel, Potent and Selective Neurokinin-3 Receptor Antagonist. Journal of Pharmacology and Experimental Therapeutics, 281, 1303-1311.

[239] Natsugari, H., Ikeura, Y., Kamo, I., Ishimaru, T., Ishichi, Y., Fujishima, A., Tanaka, T., Kasahara, F., Kawada, M. and Doi, T. (1999) Axially Chiral 1, 7-Naphthyridine-6-Carboxamide Derivatives as Orally Active Tachykinin NK1 Receptor Antagonists: Synthesis, Antagonistic Activity, and Effects on Bladder Functions. Journal of Medicinal Chemistry, 42, 3982-3993. http://dx.doi.org/10.1021/jm990220r

[240] Frankowski, K.J., Hedrick, M.P., Gosalia, P., Li, K., Shi, S., Whipple, D., Ghosh, P., Prisinzano, T.E., Schoenen, F.J., Su, Y., Vasile, S., Sergienko, E., Gray, W., Hariharan, S., Milan, L., Heynen-Genel, S., Mangravita-Novo, A., Vicchiarelli, M., Smith, L.H., Streicher, J.M., Caron, M.G., Barak, L.S., Bohn, L.M., Chung, T.D.Y. and Aubé, J. (2012) Discovery of Small Molecule Kappa Opioid Receptor Agonist and Antagonist Chemotypes trough a HTS and Hit Refinement Strategy. ACS Chemical Neuroscience, 3, 221-236. http://dx.doi.org/10.1021/cn200128x

[241] Zheng, M.Q., Nabulsi, N., Kim, S.J., Tomasi, G., Lin, S.F., Mitch, C., Quimby, S., Barth, V., Rash, K., Masters, J., Navarro, A., Seest, E., Morris, E.D. and Carson, R.E. (2013) Synthesis and Evaluation of ${ }^{11}$ C-LY2795050 as a $\kappa$-Opioid Receptor Antagonist Radiotracer for PET Imaging. Journal of Nuclear Medicine, 54, 455-463. http://dx.doi.org/10.2967/jnumed.112.109512

[242] Urbano, M., Guerrero, M., Rosen, H. and Roberts, E. (2014) Antagonists of the Kappa Opioid Receptor. Bioorganic \& Medicinal Chemistry Letters, 24, 2021-2032. http://dx.doi.org/10.1016/j.bmcl.2014.03.040 
Scientific Research Publishing (SCIRP) is one of the largest Open Access journal publishers. It is currently publishing more than 200 open access, online, peer-reviewed journals covering a wide range of academic disciplines. SCIRP serves the worldwide academic communities and contributes to the progress and application of science with its publication.

Other selected journals from SCIRP are listed as below. Submit your manuscript to us via either submit@scirp.org or Online Submission Portal.
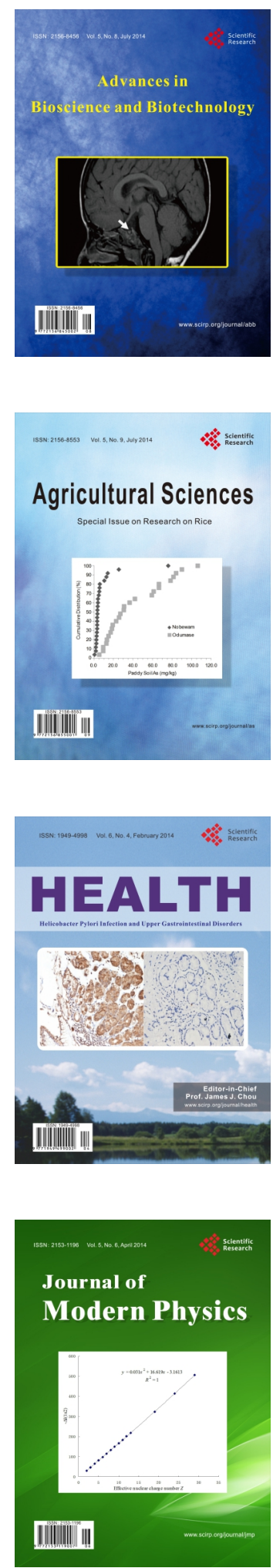
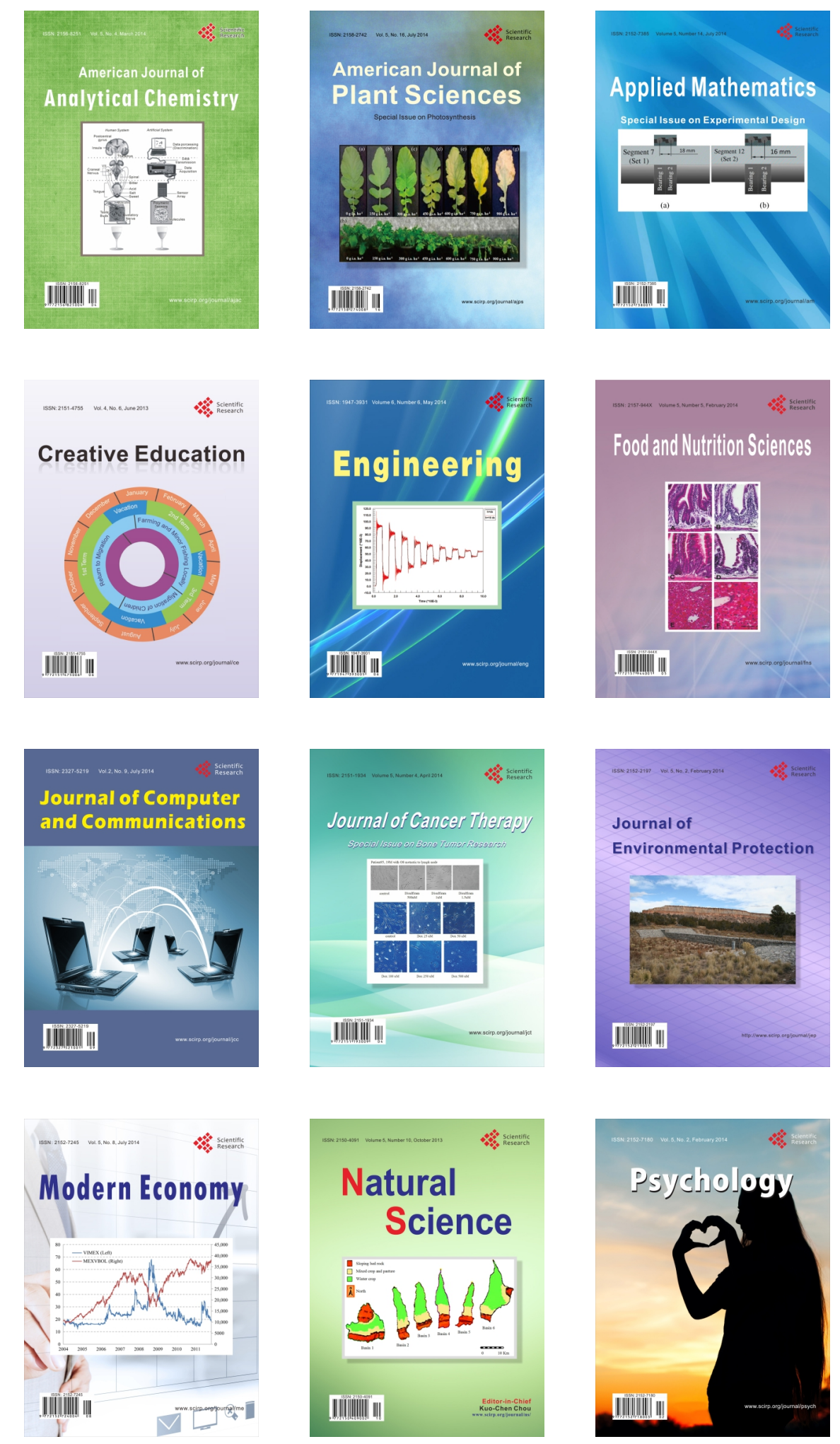